\title{
Impact of climate, vegetation, soil and crop management variables on multi-year ISBA-A-gs simulations of evapotranspiration over a Mediterranean crop site
}

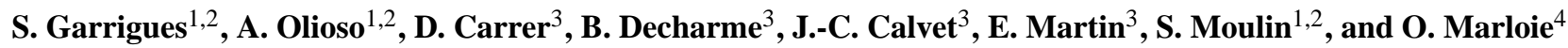 \\ ${ }^{1}$ INRA, UMR1114 EMMAH, 84914 Avignon CEDEX 9, France \\ ${ }^{2}$ Université d'Avignon et des Pays de Vaucluse, UMR1114 EMMAH, 84000 Avignon, France \\ ${ }^{3}$ CNRM-GAME, UMR3589, Météo-France, CNRS, Toulouse, France \\ ${ }^{4}$ URFM, INRA, Avignon, France
}

Correspondence to: S. Garrigues (sebastien.garrigues@paca.inra.fr)

Received: 19 December 2014 - Published in Geosci. Model Dev. Discuss.: 26 February 2015

Revised: 24 July 2015 - Accepted: 25 August 2015 - Published: 2 October 2015

\begin{abstract}
Generic land surface models are generally driven by large-scale data sets to describe the climate, the soil properties, the vegetation dynamic and the cropland management (irrigation). This paper investigates the uncertainties in these drivers and their impacts on the evapotranspiration (ET) simulated from the Interactions between Soil, Biosphere, and Atmosphere (ISBA-A-gs) land surface model over a 12-year Mediterranean crop succession. We evaluate the forcing data sets used in the standard implementation of ISBA over France where the model is driven by the SAFRAN (Système d'Analyse Fournissant des Renseignements Adaptés à la Nivologie) high spatial resolution atmospheric reanalysis, the leaf area index (LAI) time courses derived from the ECOCLIMAP-II land surface parameter database and the soil texture derived from the French soil database. For climate, we focus on the radiations and rainfall variables and we test additional data sets which include the ERA-Interim (ERA-I) low spatial resolution reanalysis, the Global Precipitation Climatology Centre data set (GPCC) and the MeteoSat Second Generation (MSG) satellite estimate of downwelling shortwave radiations.

The evaluation of the drivers indicates very low bias in daily downwelling shortwave radiation for ERA-I $\left(2.5 \mathrm{~W} \mathrm{~m}^{-2}\right)$ compared to the negative biases found for SAFRAN $\left(-10 \mathrm{~W} \mathrm{~m}^{-2}\right)$ and the MSG satellite $\left(-12 \mathrm{~W} \mathrm{~m}^{-2}\right)$. Both SAFRAN and ERA-I underestimate downwelling longwave radiations by -12 and $-16 \mathrm{~W} \mathrm{~m}^{-2}$,
\end{abstract}

respectively. The SAFRAN and ERA-I/GPCC rainfall are slightly biased at daily and longer timescales ( 1 and $0.5 \%$ of the mean rainfall measurement). The SAFRAN rainfall is more precise than the ERA-I/GPCC estimate which shows larger inter-annual variability in yearly rainfall error (up to $100 \mathrm{~mm}$ ). The ECOCLIMAP-II LAI climatology does not properly resolve Mediterranean crop phenology and underestimates the bare soil period which leads to an overall overestimation of LAI over the crop succession. The simulation of irrigation by the model provides an accurate irrigation amount over the crop cycle but the timing of irrigation occurrences is frequently unrealistic.

Errors in the soil hydrodynamic parameters and the lack of irrigation in the simulation have the largest influence on ET compared to uncertainties in the large-scale climate reanalysis and the LAI climatology. Among climate variables, the errors in yearly ET are mainly related to the errors in yearly rainfall. The underestimation of the available water capacity and the soil hydraulic diffusivity induce a large underestimation of ET over 12 years. The underestimation of radiations by the reanalyses and the absence of irrigation in the simulation lead to the underestimation of ET while the overall overestimation of LAI by the ECOCLIMAP-II climatology induces an overestimation of ET over 12 years.

This work shows that the key challenges to monitor the water balance of cropland at regional scale concern the representation of the spatial distribution of the soil hydrodynamic 
parameters, the variability of the irrigation practices, the seasonal and inter-annual dynamics of vegetation and the spatiotemporal heterogeneity of rainfall.

\section{Introduction}

Evapotranspiration (ET) is a key component of the water balance and the energy budget of land surfaces. It is essential information to represent air temperature and air humidity of the surface boundary layer (Noilhan et al., 2011) and to monitor river discharge (Habets et al., 2008). ET can be estimated from a land surface model (LSM) which describes the vertical exchange of energy and mass between the soil, the vegetation and the atmosphere at an hourly timescale. LSMs have been designed to be coupled to atmospheric or hydrology models for large-scale studies. Uncertainties in LSM simulations of ET can be attributed to (i) model structure and parameters (referred hereafter as model uncertainties) and (ii) errors in the forcing variables used to drive the model and to integrate it spatially. The forcing variables concern the climate and the land surface characteristics. They are generally provided by large-scale data sets which are characterized by coarse spatial resolution $(10-50 \mathrm{~km})$. These data sets may not be accurate enough to resolve the spatial and temporal variability of ET at regional scale. Long-term prediction of surface fluxes and water balance requires characterizing the impact of forcing variables on LSM simulations at seasonal and multi-annual scales.

Atmospheric reanalysis results from the combination of coupled atmosphere-ocean-land models and meteorological observations. One challenge concerns the evaluation of their representativeness of regional climates (Bosilovich et al., 2013). Large differences among reanalysis data sets and between these data sets and in situ observations are reported in Zhao et al. (2012). The errors are the greatest at hourly and daily time steps and generally decrease at longer timescales (Zhao et al., 2012). They can be large in mountainous regions due to unresolved topography variability and lack of dense network of measurements (Zhao et al., 2008; Wang and Zeng, 2012). Air temperature is generally a robust estimate (Quintana-Seguí et al., 2008; Decker et al., 2012). Zhao et al. (2012) evaluated four reanalysis data sets over six French sites. For air temperature, they found mean absolute errors (MAEs) which range from 0.5 to $2{ }^{\circ} \mathrm{C}$. Rainfall and radiation, which are two key external drivers of ET (Teuling et al., 2009; Miralles et al., 2011), are frequently reported as the most uncertain variables (Szczypta et al., 2011; Bosilovich, 2013). For rainfall, Zhao et al. (2012) found MAEs which range from 1.8 to $4 \mathrm{~mm} \mathrm{day}^{-1}$. The errors in precipitation particularly affect the simulation of surface flux, soil moisture and vegetation growth, which can have large impact on the simulation of hydrological variables (Decharme and Douville 2006; Maggioni et al., 2012; Anquetin et al., 2010). Regarding radiations, their estimates are frequently inaccurate due to the few number of in situ observations used to constraint the radiative transfer model used in the reanalysis (Carrer et al., 2012). Zhao et al. (2012) report daily MAEs ranging from 20 to $60 \mathrm{~W} \mathrm{~m}^{-2}$ for downwelling shortwave radiations (referred as shortwave radiation or SWdown hereafter) and from 10 to $20 \mathrm{~W} \mathrm{~m}^{-2}$ for downwelling longwave radiations (referred as longwave radiation or LWdown). Underestimations in SWdown are frequently reported over Mediterranean regions (Quintana-Seguí et al., 2008; Szczypta et al., 2011). New radiation products derived from satellite observations such as MSG/SEVIRI (MeteoSat Second Generation/Spinning Enhanced Visible and Infrared Imager) can advantageously be used over these areas that lack high resolution meteorological measurements in order to simulate the energy budget (Carrer et al., 2012).

The representation of the surface characteristics concerns all the variables used to force the model in terms of land cover type and use, vegetation dynamic and soil properties. Since the model parameters are generally prescribed per land surface type, errors in land cover maps can induce large errors in LSM outputs (Avissar and Pielke, 1989; Ge et al., 2007; Pijanowski et al., 2011). The soil texture is generally used to infer the soil hydrodynamic properties through pedotransfer functions (Espino et al., 1996; Baroni et al., 2010). It is a key variable for the spatial integration of the model since the soil properties explain a large part of ET uncertainties (Braud et al., 1995; Garrigues et al., 2015). The vegetation dynamic is represented by the leaf area index (LAI) cycle. It is a key variable involved in the simulation of canopy conductance. It is used to infer secondary parameters such as the vegetation cover which controls evapotranspiration partitioning. The LAI cycle can be described by climatology or satellite observations. Several studies have reported great discrepancies between distinct LAI satellite observations (Garrigues et al., 2008; Lafont et al., 2012). Their spatial and temporal resolution may not be fine enough to represent the cropland dynamic. Garrigues et al. (2015) highlight the large impact of the succession of crop cycle and inter-crop periods on the temporal dynamic of ET over a long period of time. Finally, agricultural land management such as irrigation can significantly influence the surface energy and water balance (de Rosnay et al., 2003; Olioso et al., 2005; Puma and Cook, 2010) but irrigation is rarely accounted for in land surface modelling at large scale.

This work aims at

1. evaluating the uncertainties in the forcing data sets used to drive land surface models at large scale,

2. assessing the relative influence of the model drivers on the simulation of ET over a 12-year Mediterranean crop succession.

We focus on the following drivers of ET:

- the rainfall and radiation climate variables, 
- the irrigation,

- the vegetation dynamic (LAI cycle),

- the soil properties (soil texture, hydrodynamic parameters).

We use the Interactions between Soil, Biosphere, and Atmosphere (ISBA) land surface model (Noilhan and Planton, 1989; Noilhan and Mahfouf, 1996) in its A-gs version (coupled photosynthesis-stomatal conductance model) (Calvet et al., 1998). We evaluate the forcing data sets used in the standard implementation of ISBA-A-gs over France. This includes the SAFRAN (Système d'Analyse Fournissant des Renseignements Adaptés à la Nivologie) high spatial resolution atmospheric reanalysis (Quintana-Seguí et al., 2008), the LAI cycles derived from the ECOCLIMAP-II land surface parameter database (Faroux et al., 2013) and the soil texture derived from the French soil database (King et al., 1995). These forcing data sets are operationally used in the SIM (SAFRAN-ISBA-MODCOU) system which is dedicated to hydrological monitoring (Habets et al., 2008; Vidal et al., 2010a) and the LDAS (Land Data Assimilation System) which combines the ISBA-A-gs model and satellite observations to monitor vegetation and soil moisture (Barbu et al., 2014). For the climate, additional data sets used for the implementation of ISBA at the continental scale are tested, which include the ERA-Interim low spatial resolution reanalysis (Simmons et al., 2010), the Global Precipitation Climatology Centre data set (GPCC; Schneider et al., 2011) and the MSG satellite estimate of downwelling shortwave radiations (Carrer et al., 2012). We chose to evaluate the forcing variables over a crop site for which the irrigation and the succession of crop and inter-crop periods are critical drivers of ET dynamics. Besides, the impact of the forcing variables over a crop succession has not yet been addressed. The evaluation is done for Mediterranean climate, for which the errors in the reanalysis estimates of radiation and rainfall were reported to be large (Szczypta et al., 2011). The evaluation is carried out at local scale over the Avignon "Remote Sensing and Fluxes" crop site (southeast of France), which is representative of typical Mediterranean cropland. This site provides 12 years of continuous measurements of micrometeorological variables and surface fluxes which allow evaluating the forcing variables and their impact on ET for a large range of surface and atmospheric states. We will first evaluate the large-scale forcing data sets against the local values taken at the Avignon site. Then, we will assess the hierarchy of the influence of the tested drivers on ET. We finally discuss the implications of our results with respect to the spatial integration of the model to monitor the water balance of cropland at regional scale.

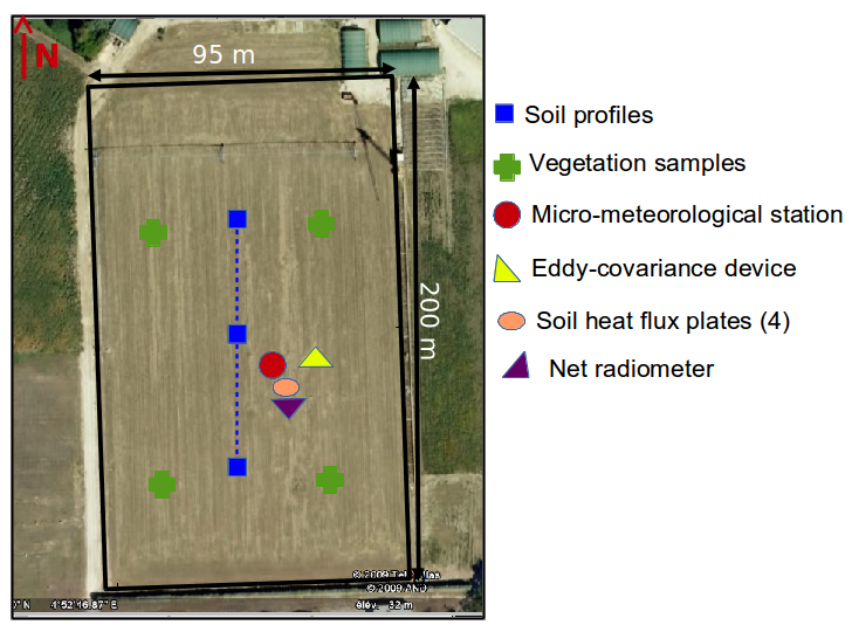

Figure 1. Map of the field site and locations of the instruments. Image from Google Earth, 2015.

\section{Site and in situ data}

We provide here the main characteristic of the Avignon experimental site, details can be found in Garrigues et al. (2015).

\subsection{Site characteristics}

The forcing data sets and the ET simulations are evaluated over the "Remote sensing and flux site" of INRA Avignon $^{1}$ (France; $43^{\circ} 55^{\prime} 00.4^{\prime \prime} \mathrm{N}, 4^{\circ} 52^{\prime} 41.0^{\prime \prime} \mathrm{E}$ (WGS84 system); $32 \mathrm{~m}$ a.s.l). This site is characterized by a Mediterranean climate with a mean annual temperature of $14{ }^{\circ} \mathrm{C}$ and a mean annual precipitation of $687 \mathrm{~mm}$. It is a flat agricultural field of 1.9 ha oriented north-south in the prevailing wind direction (Fig. 1). The evaluation period comprises a 12-year crop succession from April 2001 to December 2012 (Table 1). The crop rotation consists in a succession of winter arable crops (wheat, peas) and spring/summer arable crops (sorghum, maize, sunflower). Periods between two consecutive crop cycles are short ( $\sim 1-1.5$ months $)$ in the case of a summer crop followed by a winter crop and can last up to 10 months in the reverse case (Fig. 2). During the inter-crop periods, the soil is mostly bare. Limited wheat regrowths occurred over short periods of time. Irrigation is triggered only for summer crops (every 2 years).

The soil texture comprises $33 \%$ clay and $14 \%$ sand. The in situ values of the soil water content at saturation, field capacity and wilting point are $0.39,0.31$ and 0.18 .

\subsection{Field measurements}

Half-hourly observations of the main climatic variables, the shortwave and longwave radiation fluxes, the turbulent heat

\footnotetext{
${ }^{1}$ https://www4.paca.inra.fr/emmah_eng/Facilities/ In-situ-facilities/Remote-Sensing-Fluxes
} 
Table 1. Definition of symbols and acronyms.

\begin{tabular}{|c|c|}
\hline BS & Bare soil \\
\hline $\mathrm{C} 3$ & C3 type of crop \\
\hline $\mathrm{C} 4$ & C4 type of crop \\
\hline$d_{2}$ & Rooting depth (m) \\
\hline ERA-I & ERA-Interim reanalysis climate data set (spatial resolution of $0.5^{\circ}$ and time step of $3 \mathrm{~h}$ ) \\
\hline ERA-I/GPCC & ERA-I climate where rainfall was corrected using the GPCC rainfall data set \\
\hline GPCC & $\begin{array}{l}\text { Global Precipitation Climatology Centre data set (version 6, Schneider et al., 2011) which gives monthly } \\
\text { quality-controlled precipitation totals }\end{array}$ \\
\hline ECOCLIMAP-II & $\begin{array}{l}\text { Land surface parameter database (spatial resolution of } 1 \mathrm{~km} \text { ) used to run the SURFEX/ISBA model at global } \\
\text { scale (Faroux et al., 2013) }\end{array}$ \\
\hline ET & Evapotranspiration (given in cumulative value in millimetres at daily or multi-year timescales) \\
\hline$f_{\text {clay }}$ & Clay fraction \\
\hline$f_{\text {sand }}$ & Sand fraction \\
\hline FSDB & $\begin{array}{l}\text { French Soil DataBase (King et al., 1995) which provides soil texture over the SAFRAN grid at a spatial resolu- } \\
\text { tion of } 8 \mathrm{~km}\end{array}$ \\
\hline ISBA & Interactions between Soil, Biosphere, and Atmosphere (ISBA) Land surface model \\
\hline ISBA-A-gs & $\begin{array}{l}\text { A-gs version of ISBA. A-gs indicates that ISBA includes a coupled stomatal conductance-photosynthesis } \\
\text { scheme }\end{array}$ \\
\hline LAI & Leaf area index $\left(\mathrm{m}^{2} \mathrm{~m}^{-2}\right)$ \\
\hline LE & Latent heat flux ( $\left.\mathrm{W} \mathrm{m}^{-2}\right)$ \\
\hline LSM & Land surface model \\
\hline MaxAWC & Maximum available water content. It represents the maximum water stock available for the crop's growth \\
\hline MD & Mean deviation \\
\hline MSG & $\begin{array}{l}\text { MeteoSat Second Generation satellite. We used the downwelling shortwave radiation derived from MSG obser- } \\
\text { vations }\end{array}$ \\
\hline$r$ & Correlation coefficient \\
\hline RMSD & Root mean square of differences (between two simulations) \\
\hline SAFRAN & $\begin{array}{l}\text { Système d'Analyse Fournissant des Renseignements Adaptés à la Nivologie providing data for the snow model. } \\
\text { The SAFRAN reanalysis covers France with a spatial resolution of } 8 \mathrm{~km} \text { and an hourly time step }\end{array}$ \\
\hline SD & Standard deviation \\
\hline SDD & Standard deviation of the differences \\
\hline SEVIRI & Spinning Enhanced Visible and Infrared Imager instrument on board the MeteoSat Second Generation satellite \\
\hline SURFEX & $\begin{array}{l}\text { Surface externalisee in French. SURFEX is an externalized land and ocean surface platform that describes the } \\
\text { surface fluxes and the evolution of four types of surface: nature, town, inland water and ocean. ISBA is the land } \\
\text { surface model used for nature surfaces }\end{array}$ \\
\hline SWdown & Downwelling shortwave radiation \\
\hline LWdown & Downwelling longwave radiation \\
\hline$\theta_{\mathrm{fc}}$ & Volumetric soil moisture at field capacity $\left(\mathrm{m}^{3} \mathrm{~m}^{-3}\right)$ \\
\hline$\theta_{\text {sat }}$ & Volumetric soil moisture at saturation $\left(\mathrm{m}^{3} \mathrm{~m}^{-3}\right)$ \\
\hline$\theta_{\mathrm{wp}}$ & Volumetric soil moisture at wilting point $\left(\mathrm{m}^{3} \mathrm{~m}^{-3}\right)$ \\
\hline
\end{tabular}

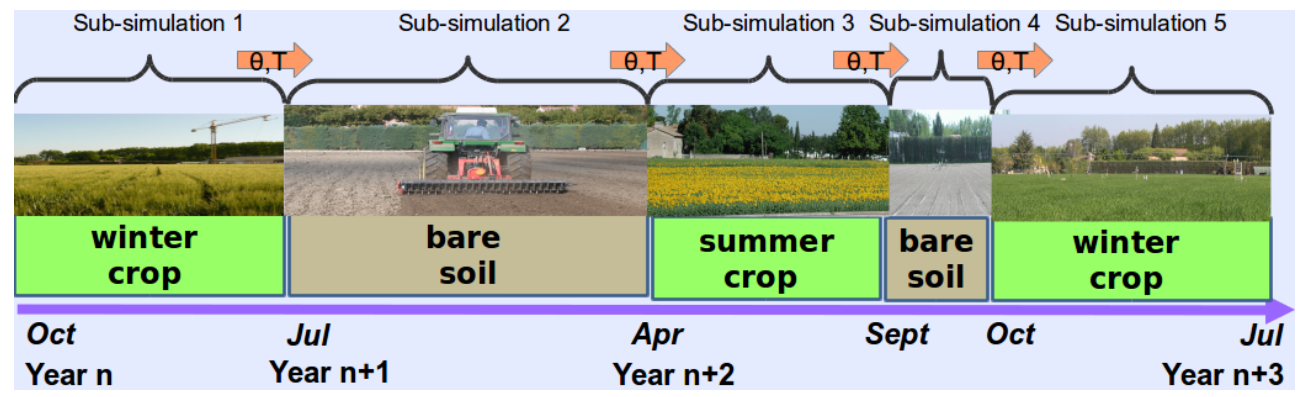

Figure 2. Illustration of the typical succession of winter and summer crops over the Avignon site and implementation of the crop succession in the simulations. $\theta$ and $T$ represent soil moisture and soil temperature transmitted from one sub-simulation to the following one. 
fluxes (eddy-covariance measurements of ET), the ground heat flux, and the soil moisture vertical profile have been continuously monitored since 2001.

The crop characteristics (LAI, height, biomass) were regularly measured at selected phenological stages. The vegetation height was linearly interpolated on a daily basis. Daily interpolation of LAI was achieved using a functional relationship between LAI and the sum of degree days (Duveiller et al., 2011).

These measurements were used to drive or evaluate the model over the crop succession.

\section{The ISBA-A-gs model}

The ISBA model (Noilhan and Planton, 1989; Noilhan and Mahfouf, 1996) is developed at the CNRM/Météo-France (National Centre for Meteorological Research/French Meteorological Service) within the SURFEX (Surface externalisée) surface modelling platform (Masson et al., 2013). In this study, we used the version 6.1 of SURFEX.

ISBA relies on a single surface energy budget of a soilvegetation composite. The soil water transfers are simulated using a force-restore scheme. They are represented by the time course of the volumetric soil moisture of three reservoirs: the superficial reservoir of thickness $d_{1}=0.01 \mathrm{~m}$ to regulate the soil evaporation, the root zone and the deep reservoir which extends from the base of the root zone to the total soil column depth. The total latent heat flux is simulated by computing individual estimates of soil evaporation and plant transpiration fluxes. Detailed explanations on how soil evaporation is computed can be found in Garrigues et al. (2015). The stomatal conductance used to compute the plant transpiration is simulated using the A-gs version of ISBA. The latter explicitly represents the functional coupling between the stomatal conductance ( $\mathrm{gs}$ ) and the net assimilation of $\mathrm{CO}_{2}(\mathrm{~A})$. The stomatal conductance for water vapour is computed as a function of the net assimilation of $\mathrm{CO}_{2}(\mathrm{Cal}-$ vet et al., 1998). A-gs is based on the model of Goudriaan et al. (1985) modified by Jacobs et al. (1996). The net assimilation of $\mathrm{CO}_{2}$ is first computed at the leaf scale, accounting for the limiting effects of the air $\mathrm{CO}_{2}$ concentration and radiation. The simulation of photosynthesis is mainly driven by the $\mathrm{CO}_{2}$ mesophyll conductance which represents the response curve of the light-saturated net rate of $\mathrm{CO}_{2}$ assimilation to the internal $\mathrm{CO}_{2}$ concentration. The stomatal conductance for $\mathrm{CO}_{2}$ and water vapour are derived from the net assimilation of $\mathrm{CO}_{2}$ using a flux-gradient relationship which accounts for the effect of air humidity deficit on stomatal aperture. The interactions between the diffusion of $\mathrm{CO}_{2}$ and water vapour is accounted through an iterative process. Two types of plant response to soil water stress are represented depending on the evolution of the water use efficiency. For drought-avoiding plants (e.g. C3 crops), the stomatal conductance and the plant transpiration are reduced by increas- ing the sensitivity of stomatal aperture to air humidity deficit while the net assimilation of $\mathrm{CO}_{2}$ is kept up by increasing the mesophyll conductance. In this strategy, water stress increases the plant water use efficiency. For drought-tolerant plants (e.g. C4 crops), the stomatal conductance is increased while the net assimilation of $\mathrm{CO}_{2}$ is depleted. In this strategy, the water use efficiency is reduced. Under a critical fraction of the root-zone water reservoir, severe stress is triggered and both the net assimilation of $\mathrm{CO}_{2}$ and plant transpiration are depleted. Photosynthesis and stomatal conductance are integrated over the canopy. A spherical angular distribution of leaves and homogeneous leaf vertical distribution is assumed to compute the radiation extinction through the canopy. While ISBA-A-gs can simulate vegetation dynamics, in this work the model is forced by the LAI which is considered an external driver. Refer to Calvet et al. (1998) for the photosynthesis and stomatal conductance equations and to Calvet et al. (2012) for further explanation on water stress function parametrization. Detailed descriptions and equations of the model can also be found in the SURFEX scientific documentation (http://www.cnrm.meteo.fr/surfex/ IMG/pdf/surfex_scidocv2.pdf, p. 121-135).

ISBA-A-gs is also able to simulate irrigation amounts for $\mathrm{C} 4$ irrigated crops. This consists in adding an amount of $30 \mathrm{~mm}$ to the rainfall input each time the simulated available soil water capacity reaches a predefined threshold (Calvet et al., 2008).

The model is parametrized and run for 12 generic land surface patches which includes nine types of vegetation. Model outputs are provided at the surface patch scale or at the grid scale using the proportion of each land surface patch within the simulation grid cell. In the standard implementation of the model, the soil depths, the vegetation parameters and the LAI cycles are given by the ECOCLIMAP-II land surface parameter database (described below). The soil parameters are derived from soil texture using the pedotransfer functions embedded in the model which rely on the Clapp and Hornberger (1978) soil texture classification (Noilhan and Lacarrère, 1994).

\section{Forcing data sets}

\subsection{Climate data sets}

\subsubsection{SAFRAN reanalysis}

The SAFRAN data set is produced by Météo-France. It provides a reanalysis of the climate variables at $8 \mathrm{~km}$ horizontal spatial resolution and hourly timescale over France back to 1958 (Quintana-Seguí et al., 2008; Vidal et al., 2010b). The reanalysis is performed over climatically homogeneous zones covering the French territory. Vertical profiles (vertical resolution of $300 \mathrm{~m}$ ) of temperature, humidity and wind speed are computed every $6 \mathrm{~h}$ from optimal interpo- 
lation between the simulations from an atmospheric model (ARPEGE, with a spatial resolution of $\sim 20-30 \mathrm{~km}$; Déqué et al., 1994) and the available in situ observations (acquired by $\sim 600$ stations over France). The downwelling shortwave and longwave radiations are derived from a radiative transfer scheme which is not constrained by observations (Ritter and Geleyn, 1992). The precipitation is computed on a daily basis from optimal interpolation between a climatology and the rain gauge observations within the climatic zone. All analysed variables are temporally interpolated to hourly values using physical constraints. They are projected over an $8 \mathrm{~km}$ Lambert grid. For temperature, humidity, wind speed and radiation variables, it consists in affecting to each grid cell the value of the vertical profile of the variable at the elevation of the grid cell.

\subsubsection{ERA-Interim reanalysis}

The ERA-Interim (ERA-I) reanalysis is produced by the ECMWF (European Centre for Medium-Range Weather Forecasts) at a spatial resolution of $0.5^{\circ}$ and $3 \mathrm{~h}$ time step. The reanalysis is based on a 4D-VAR (4-D variational) data assimilation scheme using the meteorological observations within a 03:00:00-15:00:00 UTC window (Simmons et al., 2010). Poor performances have been reported for ERA-I rainfall (Szczypta et al., 2011). The bias in ERA-I rainfall is corrected using the Global Precipitation Climatology Centre data set (GPCC v6; Schneider et al., 2011). The latter provides monthly quality-controlled precipitation totals from 1901 to present which were derived from data from 67200 rain gauge stations worldwide. The GPCC-corrected ERA-I rainfall will be denoted ERA-I/GPCC hereafter.

\subsubsection{MSG satellite downwelling shortwave radiation}

In the framework of the Land Surface Analysis Satellite Application Facility (LSA SAF), downwelling shortwave radiation is derived from the SEVIRI instrument on board the MSG satellite at a temporal frequency of $30 \mathrm{~min}$ and spatial resolution of $3 \mathrm{~km}$. This data set is available at http: //landsaf.meteo.pt. The product characteristics and the estimation method are given in Geiger et al. (2008) and Carrer et al. (2012). Under cloudy-sky conditions, shortwave radiation is estimated using the strong anti-correlation between the reflectance measured by the satellite and the solar radiation reaching the ground. Under clear-sky conditions, shortwave radiation is estimated using an atmospheric transmittance model (Geiger et al., 2008). The MSG satellite data set is available as of 12 October 2004. Before this date, the SAFRAN shortwave radiation is used. Missing MSG data represent $7 \%$ of the 12 October 2004-26 June 2012 period and were replaced by the SAFRAN estimates. The MSG estimate of downwelling longwave radiation was not available for this work. Carrer et al. (2012) showed that this product has no significant impact on the scores of the ISBA simula- tions and that the MSG shortwave radiation has the largest added value.

\subsection{Surface characteristic data sets}

The ECOCLIMAP-II database provides the land surface parameters and the LAI cycles for $\sim 273$ distinct land covers over Europe at $1 \mathrm{~km}$ resolution (Masson et al., 2003; Faroux et al., 2013). Each land cover class at $1 \mathrm{~km}$ is characterized by the fractions of the model land surface patch. The LAI and the soil depths vary with both the land cover class (geographic location-dependent) and the 12-model land surface patches while the rest of surface parameters only depend on the model land surface patch. ECOCLIMAP-II provides a monthly LAI climatology obtained from the analysis of the MODIS (Moderate Resolution Imaging Spectroradiometer) satellite observations over each land cover and land surface patch of the model (Faroux et al., 2013). For crops, the fraction of vegetation cover and the vegetation height are derived using empirical functions of LAI (Masson et al., 2003).

In the standard implementation of the model over France, the soil texture is provided by the French Soil DataBase (FSDB) on a 1:1000000 scale map (King et al., 1995) which has been resampled over the SAFRAN grid at $8 \mathrm{~km}$ resolution (Habets et al., 2008).

\section{Methodology}

\subsection{Model implementation at the Avignon site}

Continuous simulations are performed from 25 April 2001 to 26 June 2012. The model is forced either by local or reanalysis climate observations. Depending on the simulation, irrigation is added or not to rainfall. The model is driven by 10-day LAI and vegetation height derived from the ECOCLIMAP-II climatology or local observations.

We explicitly represent the succession of crop and intercrop periods in the simulations by changing the model land surface patch and the associated LAI and vegetation parameters accordingly to the crop schedule presented in Table 1 . The $\mathrm{C} 3$ crop patch was used to represent wheat, pea, and sunflower. The $\mathrm{C} 4$ crop patch was used for maize and sorghum. Inter-crop periods are represented by the bare soil patch. When the LAI climatology is used, we use the LAI cycle and the derived vegetation height provided by the ECOCLIMAPII database for each crop patch. When the local LAI is used, the LAI time trajectory depicts the dynamic of the crop succession. LAI is null for the inter-crop periods.

The simulations were initialized once on 25 April 2001 using in situ soil temperature and soil moisture measurements. The 12-year period was split into sub-simulation periods corresponding to crop and inter-crop periods (Fig. 2). To ensure the continuity between two contiguous sub-simulations, each sub-simulation was initialized using the simulated soil moisture and soil temperature of the last time step of the previ- 


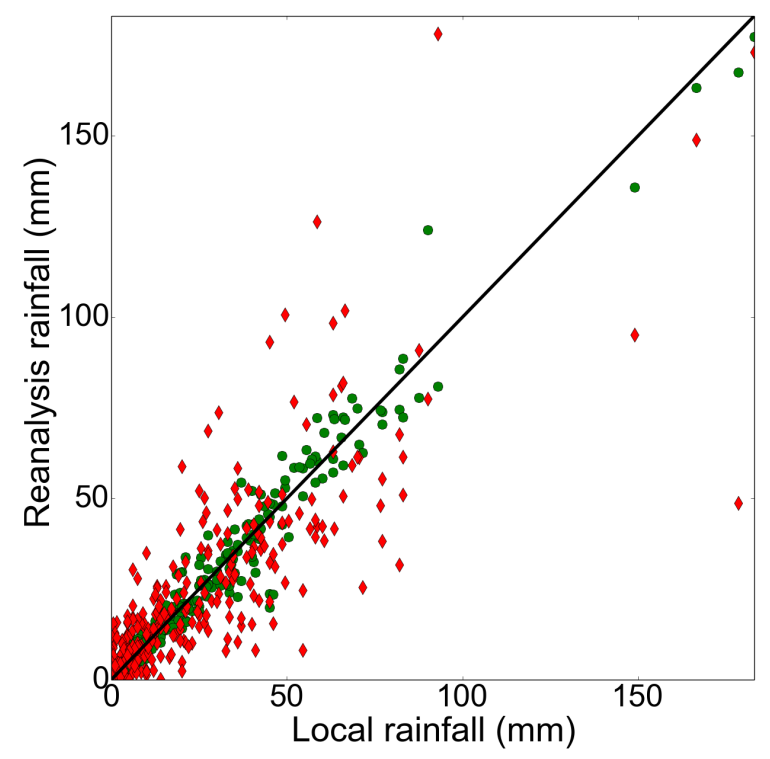

Figure 3. Evaluation of ERA-I/GPCC (red diamond) and SAFRAN (green circle) 10-day cumulative rainfall against local observations.

ous sub-simulation. The model was run at a 5 min time step. The 30 min outputs of the state variables were analysed at the model land surface patch scale (C3 crop, C4 crop, bare soil). We do not consider the outputs aggregated at $1 \mathrm{~km}$ resolution which does not match the local field scale.

\subsection{Experiment design}

This work aims at evaluating the forcing data sets used to drive the model at large scale and assessing their impacts on simulated ET. We test the following drivers of ET:

- the climate with a focus on rainfall and radiations,

- the irrigation,

- the vegetation dynamic represented by the LAI and the vegetation height time courses,

- the soil properties (soil texture, hydrodynamic parameters).

To address these issues, we designed the following simulations.

\subsubsection{Control run}

The control run $\left(\mathrm{S}_{\mathrm{CTL}}\right)$ is performed using the local observations taken at the Avignon site for the climate, the irrigation, the vegetation dynamic and the soil properties. The irrigation was accounted for by adding the actual irrigation amount to rainfall. We use the local values of the soil moisture at saturation, the soil moisture at field capacity and the soil moisture at wilting derived from field measurements of soil moisture (Garrigues et al., 2015) instead of the pedotransfer function estimates used in the standard implementation of the model. The rest of the model parameters take the standard values given by the ECOCLIMAP-II database for the $\mathrm{C} 3$ crop, the $\mathrm{C} 4$ crop and the bare soil patches (Gibelin et al., 2006; Faroux et al., 2013). The root-zone depth and the deep reservoir size are 1.5 and $0.5 \mathrm{~m}$, respectively. The performance of $\mathrm{S}_{\mathrm{CTL}}$ was evaluated in Garrigues et al. (2015), who showed good agreement with eddy-covariance measurements (MD in daily ET of $0.07 \mathrm{~mm} \mathrm{day}^{-1}$ ). In this paper, $\mathrm{S}_{\mathrm{CTL}}$ will thus be considered as truth to evaluate the other experiments and eddy-covariance measurements of ET will not be used.

\subsubsection{Experiments}

We designed nine experiments to test the impact of each driver on ET. These simulations are derived from $\mathrm{S}_{\mathrm{CTL}}$ by replacing the local values used for the tested variable by its value used in the standard implementation of the model at large scale (Table 3 ). We test the drivers one by one as follows.

\section{Impact of climate}

The local climate is replaced by the large-scale reanalysis observations. We test the following.

- The reanalysis data set: $\mathrm{S}_{\mathrm{SAFRAN}}$ and $\mathrm{S}_{\mathrm{ERA}}$ are conducted using the SAFRAN and ERA-I climate, respectively.

- The rainfall data set: $\mathrm{S}_{\mathrm{GPCC}}$ is achieved with the SAFRAN climate where the SAFRAN rainfall is replaced by the ERA-I/GPCC rainfall.

- The satellite estimate of shortwave radiation: $\mathrm{S}_{\mathrm{MSG}}$ is achieved with the SAFRAN climate where the SAFRAN downwelling shortwave radiation is replaced by the MSG estimate.

\section{Impact of irrigation}

Two aspects are tested.

- The impact of lack of irrigation in the simulation: $\mathrm{S}_{\mathrm{NO} \text {-IRRIG }}$ is performed without accounting for irrigation as it is frequently done for the standard implementation of land surface models at large scale.

- The skills of the model at representing the irrigation needs for Mediterranean crops: $\mathrm{S}_{\text {MODEL-IRRIG is }}$ achieved triggering the ISBA irrigation scheme.

\section{Impact of vegetation dynamic}

SECO-LAI is achieved with the ECOCLIMAP-II LAI and vegetation height instead of using their local value. 
Table 2. 2001-2012 crop succession. $T$ and rain are the mean temperature and cumulative precipitation, respectively, over the crop cycle.

\begin{tabular}{llllrrrr}
\hline Year & Crop & $\begin{array}{l}\text { Sowing } \\
\text { date }\end{array}$ & $\begin{array}{l}\text { Harvest } \\
\text { date }\end{array}$ & $\begin{array}{r}\text { Rain } \\
(\mathrm{mm})\end{array}$ & $\begin{array}{r}T \\
\left({ }^{\circ} \mathrm{C}\right)\end{array}$ & $\begin{array}{r}\text { Irrigation } \\
(\mathrm{mm})\end{array}$ & $\begin{array}{r}\text { Simulated } \\
\text { irrigation }(\mathrm{mm})\end{array}$ \\
\hline 2001 & Maize & 25 Apr 2001 & 28 Sep 2001 & 232.0 & 20.7 & 375 & 330 \\
2002 & Wheat & 23 Oct 2001 & 02 Jul 2002 & 399.0 & 11.6 & 0 & NA \\
2003 & Sunflower* & 16 Apr 2003 & 26 May 2003 & 68.0 & 17.1 & 40 & 0 \\
2003 & Sunflower & 02 Jun 2003 & 19 Sep 2003 & 68.5 & 24.8 & 225 & 300 \\
2004 & Wheat & 07 Nov 2003 & 28 Jun 2004 & 422.0 & 11.2 & 0 & NA \\
2005 & Peas & 13 Jan 2005 & 22 Jun 2005 & 203.5 & 11.9 & 100 & 60 \\
2006 & Wheat & 27 Oct 2005 & 27 Jun 2006 & 256.0 & 10.7 & 20 & NA \\
2007 & Sorghum & 10 May 2007 & 16 Oct 2007 & 168.5 & 20.6 & 80 & 330 \\
2008 & Wheat & 13 Nov 2007 & 01 Jul 2008 & 502.5 & 11.7 & 20 & NA \\
2009 & Maize* & 23 Apr 2009 & 15 Jun 2009 & 110.5 & 19.2 & 80 & 0 \\
2009 & Sorghum & 25 Jun 2009 & 22 Sep 2009 & 89.0 & 23.6 & 245 & 270 \\
2010 & Wheat & 19 Nov 2009 & 13 Jul 2010 & 446.5 & 11.6 & 0 & NA \\
2011 & Sorghum & 22 Apr 2011 & 22 Sep 2011 & 268.5 & 21.4 & 60 & 120 \\
2012 & Wheat & 19 Oct 2011 & 25 Jun 2012 & 437.0 & 12.0 & 0 & NA \\
\hline
\end{tabular}

* These crops were interrupted and replaced by a new one.

\section{Impact of soil properties}

Two aspects are investigated.

- The impact of errors in soil texture which is used as input of the pedotransfer functions to estimate the soil hydrodynamic parameters.

- The impact of errors in the soil hydrodynamic parameters estimated from the pedotransfer function. We consider the soil moisture at saturation, the soil moisture at field capacity and the soil moisture at wilting point, which represent the main sources of uncertainties in simulated ET when the model is implemented at local scale (Garrigues et al., 2015).

To investigate both issues, two simulations are performed by replacing the local values of the soil hydrodynamic properties used in $\mathrm{S}_{\mathrm{CTL}}$ by their pedotransfer estimates:

- S Socal-TEXT, achieved using the local soil texture,

- SFSDB-TEXT, achieved using the texture value from the French Soil DataBase (FSDB).

\subsection{Evaluation method}

We first evaluate the large-scale forcing data sets against the local observations taken at the Avignon site. Due to the low topographic variability of the area, the climate observations of the Avignon site are representative of the area covered by the reanalysis grid. This particularly holds true for radiation but larger variability can be found for precipitation. The large-scale vegetation and soil data cannot exactly match the local ones but their evaluation at local scale brings insight into their representativeness of typical cropland and soil type of Mediterranean regions.
Then, we assess the influence of each driver on simulated ET by comparing each experiment achieved with the large-scale data set with the control run achieved with the local observation. We report the scattering in LE at halfhourly timescales and the scattering in cumulative ET at daily, monthly, seasonal and 12-year timescales.

The scattering between the forcing data sets and the local observations as well as the scattering between each experiment and the control run are quantified using the root mean square of difference (RMSD), the mean difference (MD), the SD of differences (SDD), and the correlation. The RMSD quantifies the total scattering. MD quantifies the systematic differences and SDD represents the random component of the RMSD.

\section{Results}

\subsection{Evaluation of the large-scale forcing data sets}

\subsubsection{Climate variables}

\section{Rainfall}

The evaluation of the ERA-I/GPCC and SAFRAN rainfall against local observations are reported in Table 4 and illustrated by Figs. 3, 4 and 5. Table 4 shows lower correlation and larger SDD at $3 \mathrm{~h}$ timescale than at longer timescales for both data sets (Table 4). This reveals shortcomings in the rescaling of the daily values used to build these data sets to hourly values. At daily and longer timescales, both data sets are lowly biased. However, the SAFRAN rainfall is more precise than the ERA-I/GPCC rainfall which shows lower correlation with measurements and has an SDD 3 times larger than SAFRAN (Table 4, Fig. 3). Figure 4 shows 


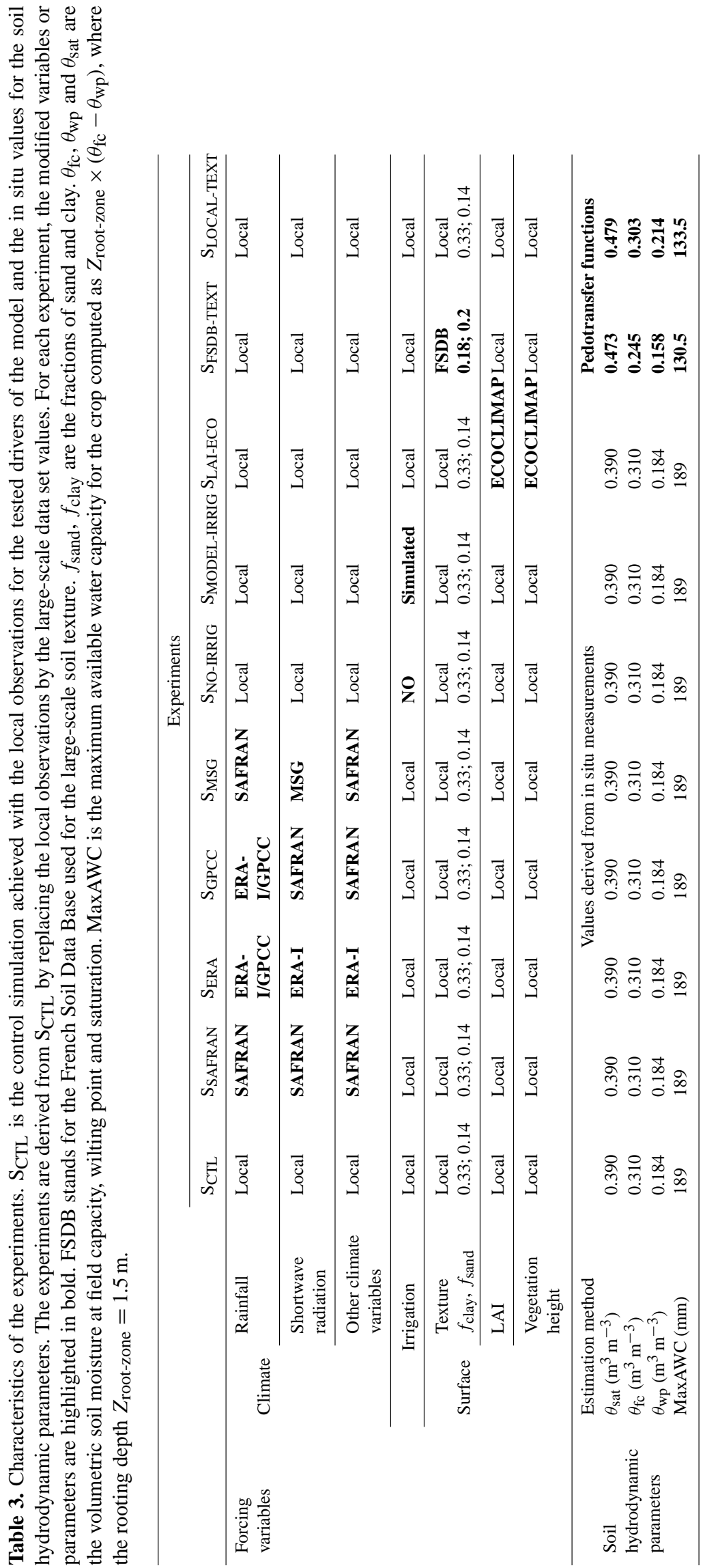




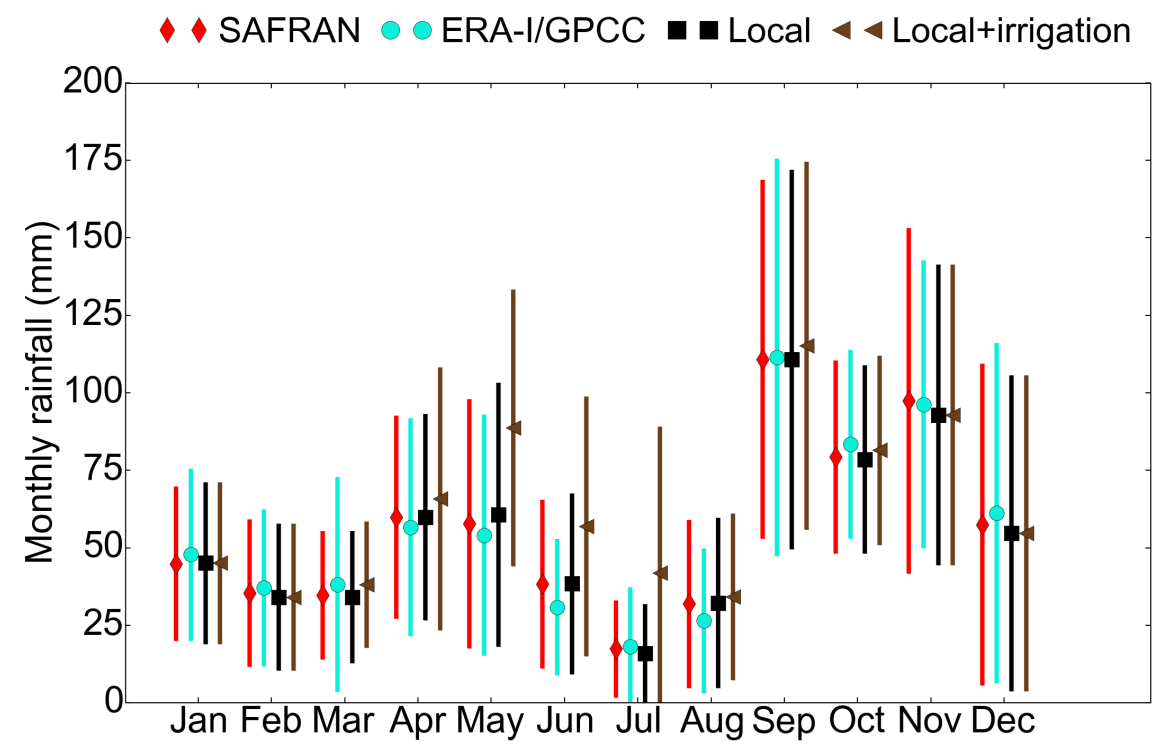

Figure 4. Comparison of SAFRAN, ERA-I/GPCC and local mean monthly rainfall. Irrigation amount added to the local rainfall is also presented. The vertical bars represent the inter-annual variability ( \pm 1 standard deviation).

Table 4. Evaluation of SAFRAN and ERA-I/GPCC cumulative rainfall against measurements over the 2001-2012 period at $3 \mathrm{~h}$, daily, 10day, 30-day and yearly timescales. SDD and MD are given in absolute value in millimetres and in percentage of the mean local measurement in parentheses.

\begin{tabular}{|c|c|c|c|c|c|c|c|c|c|c|c|c|c|c|c|}
\hline & \multicolumn{3}{|c|}{$3 \mathrm{~h}$} & \multicolumn{3}{|c|}{ Daily } & \multicolumn{3}{|c|}{ 10-day } & \multicolumn{3}{|c|}{ 30-day } & \multicolumn{3}{|c|}{ Yearly } \\
\hline Mean in situ & & 0.22 & & & 1.74 & & & 17.36 & & & 51.83 & & & 657.10 & \\
\hline & $r$ & MD & SDD & $r$ & $\mathrm{MD}$ & SDD & $r$ & MD & SDD & $r$ & MD & SDD & $r$ & MD & SDD \\
\hline SAFRAN & 0.53 & $\begin{array}{l}0.00 \\
(1 \%)\end{array}$ & $\begin{array}{l}1.46 \\
(674 \%)\end{array}$ & 0.97 & $\begin{array}{l}0.02 \\
(1 \%)\end{array}$ & $\begin{array}{l}1.57 \\
(90 \%)\end{array}$ & 0.98 & $\begin{array}{l}0.21 \\
(1 \%)\end{array}$ & $\begin{array}{l}4.48 \\
(26 \%)\end{array}$ & 0.99 & $\begin{array}{l}0.61 \\
(1 \%)\end{array}$ & $\begin{array}{l}7.03 \\
(14 \%)\end{array}$ & 0.99 & $\begin{array}{l}8.22 \\
(1 \%)\end{array}$ & $\begin{array}{l}20.14 \\
(3 \%)\end{array}$ \\
\hline ERA-I/GPCC & 0.46 & $\begin{array}{l}-0.14 \\
(66 \%)\end{array}$ & $\begin{array}{l}1.57 \\
(720 \%)\end{array}$ & 0.73 & $\begin{array}{l}0.01 \\
(0.5 \%)\end{array}$ & $\begin{array}{l}4.69 \\
(270 \%)\end{array}$ & 0.84 & $\begin{array}{l}0.09 \\
(0.5 \%)\end{array}$ & $\begin{array}{l}14.31 \\
(82 \%)\end{array}$ & 0.90 & $\begin{array}{l}0.28 \\
(0.5 \%)\end{array}$ & $\begin{array}{l}21.89 \\
(42 \%)\end{array}$ & 0.95 & $\begin{array}{l}4.45 \\
(0.7 \%)\end{array}$ & $\begin{array}{l}60.00 \\
(9.1 \%)\end{array}$ \\
\hline
\end{tabular}

that the ERA-I/GPCC rainfall is overestimated in winter and underestimated in spring and summer. The error in yearly rainfall which ranges from -81 to $98 \mathrm{~mm} \mathrm{yr}^{-1}$ for ERAI/GPCC (Fig. 5) shows larger inter-annual variability than for SAFRAN which ranges from -42 to $32 \mathrm{~mm} \mathrm{yr}^{-1}$. The use of a dense network of rain gauges over France may explain the higher precision of the SAFRAN data set, which resolves the rainfall spatial variability better over France (QuintanaSeguí., et al., 2008).

\section{Radiations}

The evaluation of SAFRAN, MSG and ERA-I shortwave and longwave radiations are reported in Table 5. SAFRAN and MSG shortwave radiations show similar negative MD $\left(\sim-10 \mathrm{~W} \mathrm{~m}^{-2}\right)$ and SDD with measurements at both halfhourly and daily timescales (Table 5). The SAFRAN shortwave radiation is underestimated at midday in summer while the MSG satellite estimate is underestimated in the after- noon. The ERA-I shortwave radiation has an absolute MD 4 times smaller than SAFRAN. It is quasi-unbiased at daily timescale. This is related to compensation effects between an underestimation of the shortwave radiations in the morning and an overestimation in the afternoon (Fig. 6).

SAFRAN and ERA-I underestimate longwave radiation by -12 and $-16 \mathrm{Wm}^{-2}$ (Table 5). Figure 7 shows that SAFRAN describes an inverse diurnal cycle of longwave radiation and underestimates the maximum value in the afternoon. The ERA-I longwave radiation shows consistent diurnal variations but it is underestimated through the diurnal and the seasonal cycles.

The errors in yearly shortwave and longwave radiations range from -661 to $-21 \mathrm{MJ}$ and from -548 to $-107 \mathrm{MJ}$, respectively, for SAFRAN (Fig. 5). They vary from -52 to $179 \mathrm{MJ}$ and from -625 to $-385 \mathrm{MJ}$, respectively, for ERA-I which shows lower inter-annual variations than SAFRAN.

The uncertainties in the reanalysis estimates of shortwave and longwave radiations are attributed to shortcomings in the 
Table 5. Evaluation of SAFRAN, ERA-I and MSG downwelling shortwave radiation (SWdown) and downwelling longwave radiation (LWdown) against measurements, over the 12 October 2004-25 June 2012 period, at $3 \mathrm{~h}$ and daily time steps. The SWdown performances of all the data sets were evaluated considering only the time steps with valid MSG SWdown, which represents $93 \%$ of the period.

\begin{tabular}{|c|c|c|c|c|c|c|c|c|c|c|c|c|}
\hline & \multicolumn{6}{|c|}{$3 \mathrm{~h}$} & \multicolumn{6}{|c|}{ Daily } \\
\hline & \multicolumn{2}{|c|}{ SWdown } & $\left(\mathrm{W} \mathrm{m}^{-2}\right)$ & \multicolumn{2}{|c|}{ LWdown } & $\left(\mathrm{W} \mathrm{m}^{-2}\right)$ & \multicolumn{2}{|c|}{ SWdown } & $\left(\mathrm{W} \mathrm{m}^{-2}\right)$ & \multicolumn{2}{|c|}{ LWdown } & $\left(\mathrm{W} \mathrm{m}^{-2}\right)$ \\
\hline & $r$ & BIAS & SDD & $r$ & BIAS & SDD & $r$ & BIAS & SDD & $r$ & BIAS & SDD \\
\hline SAFRAN & 0.97 & -9.5 & 65.8 & 0.79 & -11.9 & 29.4 & 0.95 & -9.8 & 32.5 & 0.90 & -11.9 & 19.2 \\
\hline ERA-I & 0.97 & 2.5 & 60.8 & 0.93 & -16.1 & 17.2 & 0.96 & 2.4 & 28.8 & 0.97 & -16.1 & 11.0 \\
\hline MSG & 0.96 & -11.2 & 67.6 & NA & NA & NA & 0.95 & -11.6 & 30.2 & NA & NA & NA \\
\hline
\end{tabular}

radiative transfer scheme and to an insufficient number of observations to constrain the reanalysis. Our results confirm the low bias in daily shortwave radiation reported for ERA-I in Szczypta et al. (2011). However, our work does not show higher levels of accuracy and precision for the MSG satellite estimates of shortwave radiations as reported by Carrer et al. (2012). This can be related to the high occurrence of clearsky conditions at the Avignon site for which the satellite measurements are not explicitly used. The clear-sky algorithm relies on an empirical parametrization of the atmospheric transmittance and on a climatology for the aerosol content. This may not be accurate enough to resolve the large variations in the aerosol content generated by the frequent strong wind conditions in the Avignon region. Besides, possible errors in the cloud mask used to trigger the clear-sky/cloudy-sky retrieval algorithm can have a large impact on shortwave radiation estimates (Geiger et al., 2008).

\subsubsection{Vegetation characteristics}

Figure 8 shows that ECOCLIMAP-II overestimates low LAI during the early and late stages of the crop cycles, which results in an overall overestimation of LAI over the crop cycle (positive bias of $1 \mathrm{~m}^{2} \mathrm{~m}^{-2}$ ). The maximum LAI of wheat crops (e.g. 2002, 2004, 2006) is frequently underestimated by ECOCLIMAP-II and its timing is late compared to measurements. The timing of maximum LAI is more accurate for summer crops (e.g. Sorghum in 2007 and 2009). An incorrect decrease in LAI is observed at the early stages of wheat crops.

The ECOCLIMAP-II LAI climatology is derived from the 2002-2006 MODIS satellite observations at $1 \mathrm{~km}$ spatial resolution. The first explanation of the differences between the ECOCLIMAP-II LAI and the local LAI is the spatial and temporal mismatch between the satellite observations and the local field. The $1 \mathrm{~km}$ satellite pixel is composed of bare soil and vegetation surfaces, which reduces the maximum LAI resolved by ECOCLIMAP-II. The satellite observations comprise a mix of crops with possibly distinct cycles. Therefore, a particular crop cycle cannot be represented, nor the local crop rotation. The monthly time step of ECOCLIMAP-II can be too coarse to properly resolve the changes in crop phenology, which explains the fre- quent inaccurate timing of the ECOCLIMAP-II maximum LAI. The second explanation of the differences between the ECOCLIMAP-II and the local LAI is related to the intrinsic uncertainties of the ECOCLIMAP-II LAI. ECOCLIMAP-II shows unrealistic crop cycles compared to the local LAI measurements which are representative of typical crop cycles of the studied region. As a climatology, it does not resolve the inter-annual variability. The absence of discrimination between winter and summer crop patches hampers the proper representation of the seasonal and crop succession dynamics. The inter-crop periods during which the surface can be bare during long periods of time (up to 9 months) are not represented. This leads to an underestimation of the bare soil surfaces and contributes to the overestimation of LAI over the crop succession.

\subsubsection{Irrigation}

Irrigation represents $18 \%(1295 \mathrm{~mm})$ of cumulative rainfall $(7138 \mathrm{~mm})$ over 12 years for this site. It concerns summer crops and mainly occurs from May to July. It induces much larger variation in input water for the model than the differences in rainfall estimates between reanalysis data sets (Fig. 4).

We evaluate here the skill of the model at simulating the irrigation needs for the irrigated crops of the crop succession. The total amounts of simulated irrigation over each crop cycle are in close agreement with the actual values except for sorghum in 2007 and 2011 (Table 2). MD and SDD computed over eight crop cycles are 25 and $99 \mathrm{~mm}$. However, Fig. 9 highlights the inaccurate timing of simulated irrigations. The latter are frequently underestimated in the early stages of the crop cycle (April-June), overestimated during the growing period (July) and overestimated during the crop senescence (August-September). We observe frequent overestimation of the inter-annual variability in July and August. The soil moisture thresholds used to trigger the irrigation are probably too high for the considered crops and need to be adapted for Mediterranean crops. The lack of constraints on irrigation practices probably explains the inaccurate timing of the simulated irrigations. 
a) SAFRAN

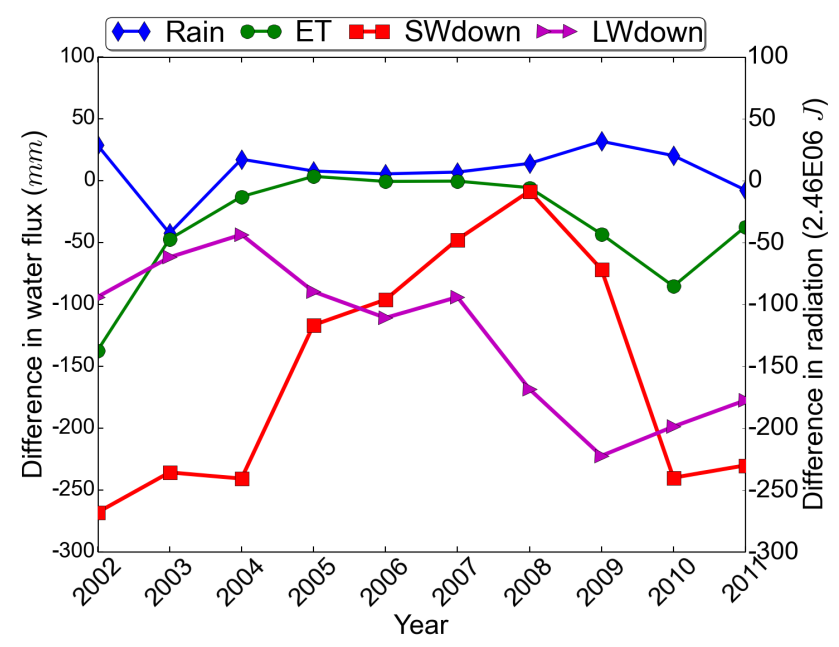

b)ERA-I/GPCC

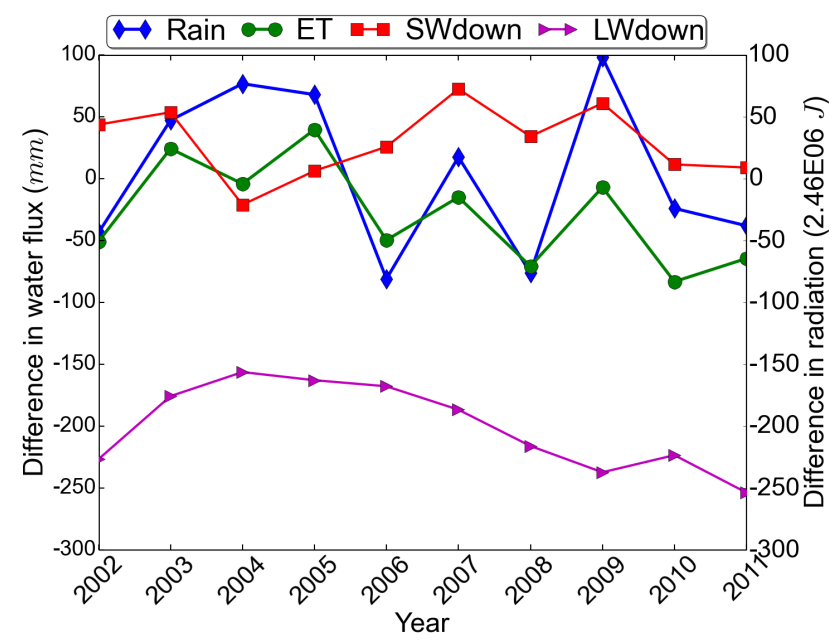

Figure 5. Evaluation of yearly values of shortwave radiation (SWdown), longwave radiation (LWdown), rainfall and simulated evapotranspiration (ET) for SAFRAN (a) and ERA-I/GPCC (b) reanalyses. For radiations and rainfall, the differences in yearly cumulative values between the reanalysis and the local observation are represented. For ET, the differences in yearly cumulative values between the simulation achieved with the reanalysis climate ( $\mathrm{S}_{\mathrm{SAFRAN}}$ and $\mathrm{S}_{\mathrm{ERA}}$ ) and the simulation achieved with the local climate $\left(\mathrm{S}_{\mathrm{CTL}}\right)$ are shown. The radiation unit is given in $2.46 \times 10^{6} \mathrm{~J}$ to match the water-flux scale given in millimetres.

\subsection{Impact on simulated ET}

Figure 10 displays the differences in cumulative ET between each experiment achieved with the large-scale data set for each tested driver and the control run $\left(\mathrm{S}_{\mathrm{CTL}}\right)$ achieved with the local observations. The scattering in daily ET between the selected experiment and $\mathrm{S}_{\mathrm{CTL}}$ is presented in Fig. 11. Table 6 reports the scattering metrics between each experiment and $\mathrm{S}_{\mathrm{CTL}}$. The Taylor diagrams given in Fig. 12 summarize the deviation between each experiment and the control run trough the correlation and the RMSD. We first provide the hierarchy of influence of the drivers on ET and then we analyse the impact of each driver on ET.

\subsubsection{Hierarchy of the influence of the drivers on ET}

Soil hydrodynamic parameters and the lack of irrigation generate the largest mean deviation in ET with the control run (Table 6, Fig. 10). The MD in cumulative ET over 12 years represents 25 and 20 months of ET for the soil parameters and the irrigation, respectively. The climate and the vegetation dynamic induces lower MD in ET, which ranges from 6 to 9 months of ET over 12 years. Changing the climate forcing data set has little influence on ET simulation compared to the impact of irrigation and soil properties. At a seasonal timescale, the irrigation and the vegetation dynamic are the drivers which induce the largest random scattering with $\mathrm{S}_{\mathrm{CTL}}$ (see RMSD in Fig. 12).

\subsubsection{Influence of soil properties}

The use of the pedotransfer estimates of the soil hydrodynamic parameters (soil moisture at field capacity, soil moisture at wilting point and soil moisture at saturation) in S SOCAL-TEXT leads to substantial underestimation of ET compared to $\mathrm{S}_{\mathrm{CTL}}$ achieved with the field estimates of these parameters. The soil moisture at saturation is involved in the representation of the hydraulic diffusivity of the superficial soil layer in the ISBA model. Its overestimation by the ISBA pedotransfer function (see values in Table 3) triggers an underestimation of the soil hydraulic diffusivity and the resulting soil evaporation. The soil moisture at wilting point is a key driver of the maximum available water capacity. Its overestimation by the ISBA pedotransfer function (Table 3) leads to the underestimation of the plant transpiration.

While the clay and sand fractions given by the French soil database are significantly different from the local values, the differences between $\mathrm{S}_{\mathrm{FSDB}} \mathrm{TEXT}$ and $\mathrm{S}_{\mathrm{LOCAL}-\mathrm{TEXT}}$ are low. Table 3 shows that the use of the large-scale soil texture and the local soil texture lead to similar values of the maximum available soil water capacity for the crop (MaxAWC). The steady MaxAWC is a consequence of the quasi-parallel shapes of the ISBA pedotransfer functions used to estimate the soil moisture at field capacity and the soil moisture at wilting point (Noilhan and Lacarrère, 1995). This highlights the limit of these pedotransfer functions to resolve the spatial variability of the soil hydrodynamic properties across various soil types.

\subsubsection{Influence of irrigation}

Irrigation substantially influences ET although it concerns only short periods of time during the crop succession. The lack of irrigation in the simulation $\mathrm{S}_{\text {NO-IRRIG }}$ triggers a sub- 

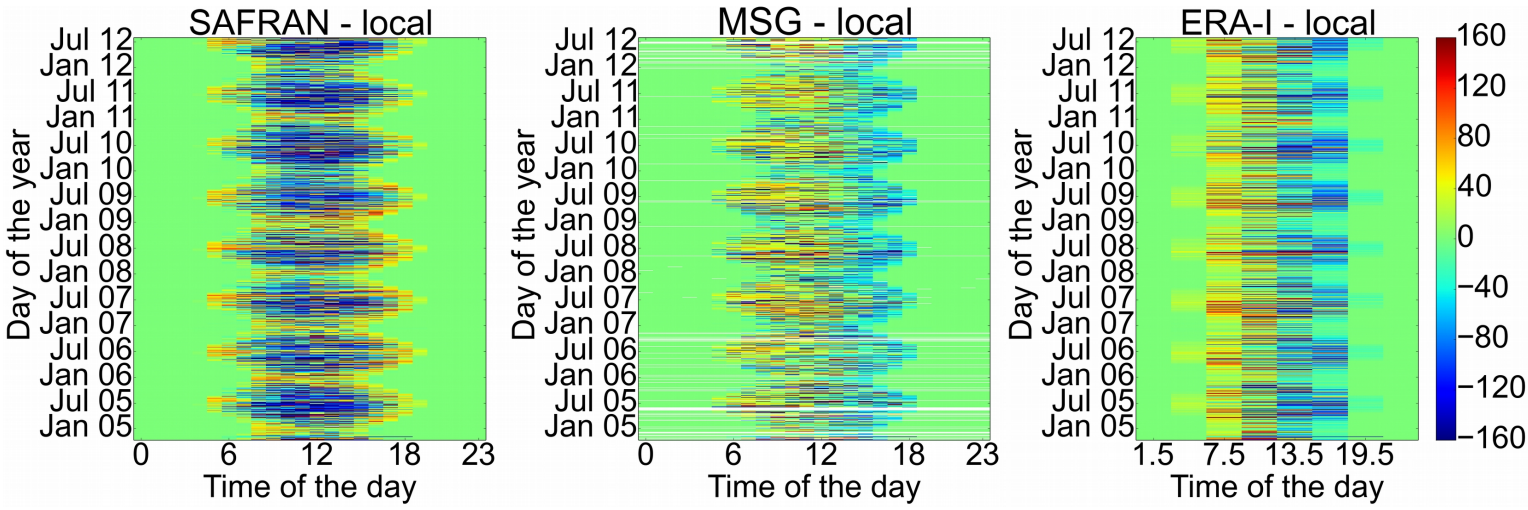

Figure 6. Evaluation of SAFRAN, ERA-I and MSG downwelling shortwave radiations against local measurements over the 12 October 2004-25 June 2012 period. Differences between the reanalysis estimates and the local measurements are computed at an hourly timescale for SAFRAN and MSG and at a $3 \mathrm{~h}$ timescale for ERA-I. In the MSG figure, the white lines correspond to missing data. On the $y$ axis, Jan and Jul stand for January and July. The two digits indicate the year.

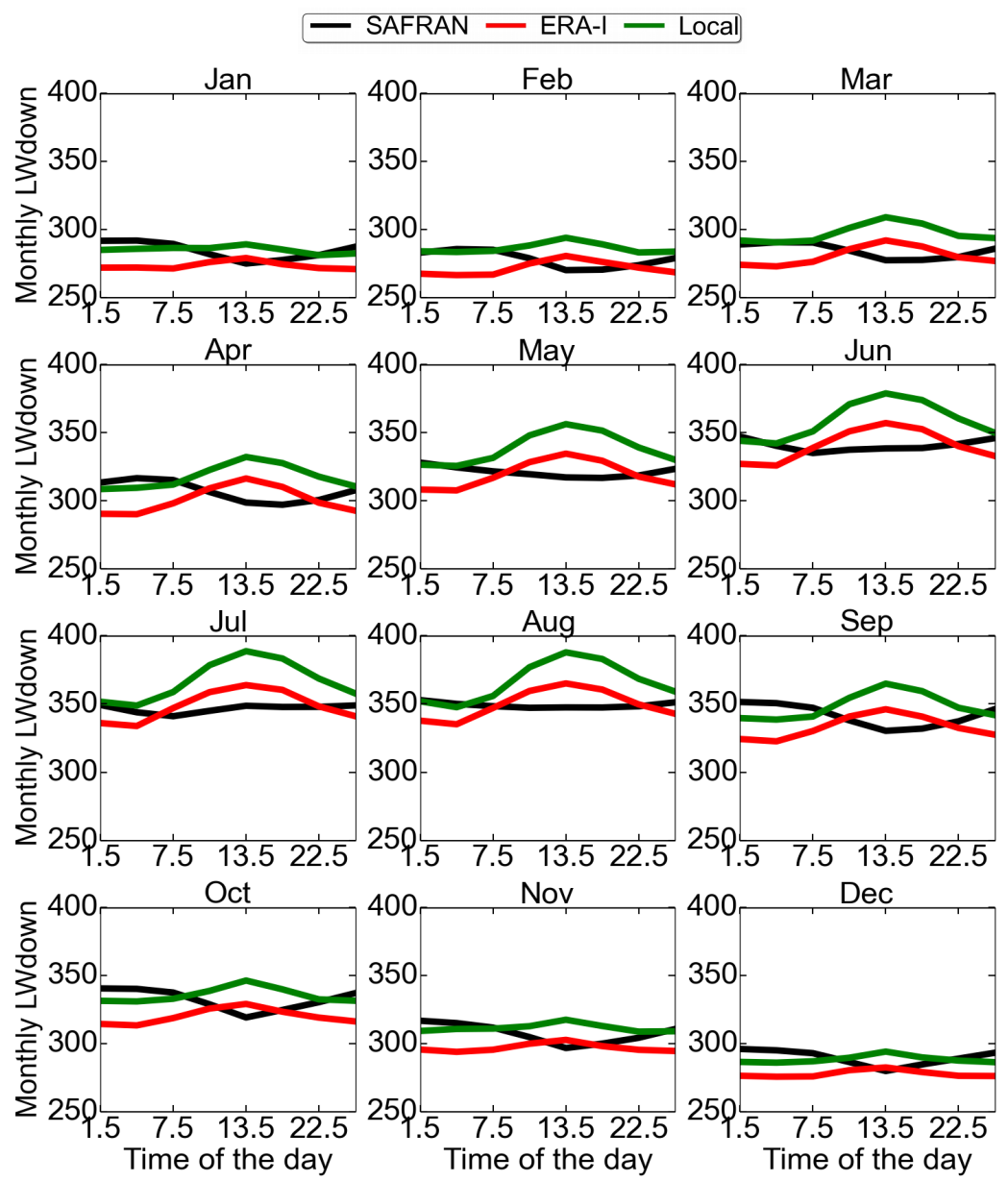

Figure 7. Comparison of SAFRAN, ERA-I and in situ mean monthly downwelling longwave radiation (LWdown in $\mathrm{W} \mathrm{m}^{-2}$ ) over the 25 April 2001-25 June 2012 period. The estimates correspond to $3 \mathrm{~h}$ integrated values. 
Table 6. Influence of the large-scale forcing variables on simulated evapotranspiration (ET) at half-hourly, daily, monthly, seasonal and multi-year timescales. The mean difference (MD) and the SD of difference (SDD) between each experiment and the control run (STL ${ }_{\mathrm{CTL}}$ computed over the 25 April 2001-26 June 2012 period. In the last column, MD in cumulative ET over 12 years is given in absolute value and in percentage of the 12-year cumulative ET obtained with the control run. This percentage is translated in equivalent number of months of ET.

\begin{tabular}{|c|c|c|c|c|c|c|c|c|c|c|c|c|}
\hline \multirow[b]{2}{*}{ Drivers } & \multirow[b]{2}{*}{$\begin{array}{l}\text { Experiment compared } \\
\text { to } \mathrm{S}_{\mathrm{CTL}}\end{array}$} & \multicolumn{2}{|c|}{$\begin{array}{l}\text { Half-hourly LE } \\
\left(\mathrm{W} \mathrm{m}^{-2}\right)\end{array}$} & \multicolumn{2}{|c|}{$\begin{array}{l}\text { Daily ET } \\
\quad(\mathrm{mm})\end{array}$} & \multicolumn{2}{|c|}{$\begin{array}{l}\text { Monthly ET }) \\
(\mathrm{mm})\end{array}$} & \multicolumn{2}{|c|}{$\begin{array}{l}\text { Seasonal ET } \\
(\mathrm{mm})\end{array}$} & \multicolumn{3}{|c|}{$\begin{array}{c}\text { 12-year cumulative } \\
\text { ET }(\mathrm{mm})\end{array}$} \\
\hline & & MD & SDD & MD & SDD & MD & SDD & MD & SDD & $\begin{array}{r}\mathrm{MD} \\
(\mathrm{mm})\end{array}$ & $\begin{array}{l}\mathrm{MD} \\
(\%)\end{array}$ & $\begin{array}{r}\text { MD } \\
\text { (months of ET) }\end{array}$ \\
\hline Soil parameters & $\begin{array}{l}\mathrm{S}_{\mathrm{FSDB}-\mathrm{TEXT}} \\
\mathrm{S}_{\text {LOCAL-TEXT }}\end{array}$ & $\begin{array}{l}-10.23 \\
-9.46 \\
\end{array}$ & $\begin{array}{l}37.30 \\
35.64\end{array}$ & $\begin{array}{c}-0.36 \\
-0.33 \\
\end{array}$ & $\begin{array}{l}0.69 \\
0.67\end{array}$ & $\begin{array}{r}-10.78 \\
-9.96 \\
\end{array}$ & $\begin{array}{l}10.85 \\
10.68\end{array}$ & $\begin{array}{l}-31.61 \\
-29.20 \\
\end{array}$ & $\begin{array}{l}21.29 \\
21.21\end{array}$ & $\begin{array}{l}-1467.7 \\
-1355.4 \\
\end{array}$ & $\begin{array}{l}19.9 \\
18.4\end{array}$ & $\begin{array}{l}26.7 \\
24.6\end{array}$ \\
\hline Irrigation & $\begin{array}{l}\mathrm{S}_{\mathrm{NO}-I R R I G} \\
\mathrm{~S}_{\text {MODEL-IRRIG }}\end{array}$ & $\begin{array}{l}-7.74 \\
-0.04\end{array}$ & $\begin{array}{c}42.80 \\
47.43\end{array}$ & $\begin{array}{r}-0.27 \\
0.00\end{array}$ & $\begin{array}{c}0.93 \\
1.06\end{array}$ & $\begin{array}{l}-8.15 \\
-0.04\end{array}$ & $\begin{array}{l}18.38 \\
19.93\end{array}$ & $\begin{array}{r}-23.75 \\
0.09\end{array}$ & $\begin{array}{l}43.52 \\
42.45\end{array}$ & $\begin{array}{r}-1117.7 \\
-6.0\end{array}$ & $\begin{array}{r}15.2 \\
0.1\end{array}$ & $\begin{array}{r}20.3 \\
0.1\end{array}$ \\
\hline $\begin{array}{l}\text { Vegetation } \\
\text { dynamics }\end{array}$ & $\mathrm{S}_{\mathrm{ECO}-\mathrm{LAI}}$ & 3.03 & 47.23 & 0.11 & 0.97 & 3.19 & 19.14 & 9.33 & 38.89 & 441.1 & 6.0 & 8.0 \\
\hline Climate & $\begin{array}{l}\mathrm{S}_{\text {SAFRAN }} \\
\mathrm{S}_{\text {ERA }} \\
\mathrm{S}_{\text {GPCC }} \\
\mathrm{S}_{\text {MSG }}\end{array}$ & $\begin{array}{l}-3.06 \\
-2.28 \\
-3.60 \\
-3.60\end{array}$ & $\begin{array}{l}45.66 \\
60.24 \\
49.78 \\
46.72\end{array}$ & $\begin{array}{l}-0.11 \\
-0.08 \\
-0.13 \\
-0.13\end{array}$ & $\begin{array}{l}0.85 \\
0.83 \\
0.95 \\
0.80\end{array}$ & $\begin{array}{r}-3.23 \\
-2.40 \\
-3.80 \\
-3.80\end{array}$ & $\begin{array}{r}10.46 \\
9.00 \\
11.26 \\
10.26\end{array}$ & $\begin{array}{r}-9.26 \\
-6.98 \\
-10.93 \\
-11.04\end{array}$ & $\begin{array}{c}20.73 \\
16.52 \\
21.72 \\
19.11\end{array}$ & $\begin{array}{l}-438.2 \\
-333.4 \\
-516.0 \\
-514.5\end{array}$ & $\begin{array}{l}5.9 \\
4.5 \\
7.0 \\
7.0\end{array}$ & $\begin{array}{l}7.9 \\
6.0 \\
9.4 \\
9.3\end{array}$ \\
\hline
\end{tabular}

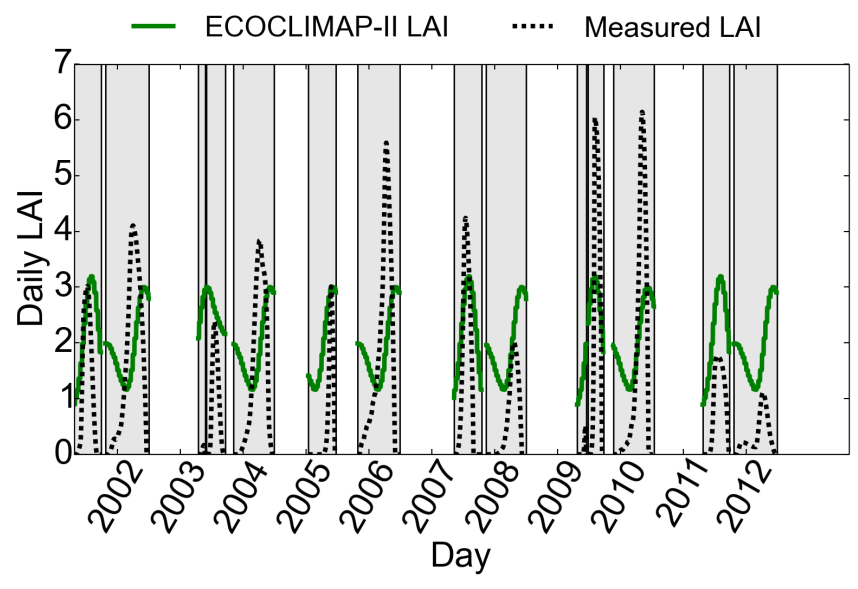

Figure 8. Comparison of the ECOCLIMAP-II LAI with the in situ LAI over the crop cycles of the 12-year crop succession. Crop and inter-crop periods are represented by grey and white backgrounds, respectively.

stantial decrease in ET during the growing periods of summer crops (Fig. 10). It leads to an underestimation in ET of $1118 \mathrm{~mm}$ over 12 years which is 2.5 times larger than the MD induced by the use of a reanalysis climate (Table 6).

The simulation of irrigation by the model ( $\mathrm{S}_{\text {MODEL-IRRIG) }}$ leads to no bias in ET over 12 years (Table 6). The large SDD

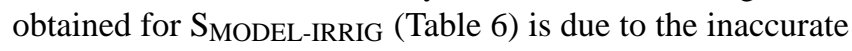
timing of the occurrences of simulated irrigation which locally triggers an overestimation or an underestimation in ET over the crop succession (Fig. 10).

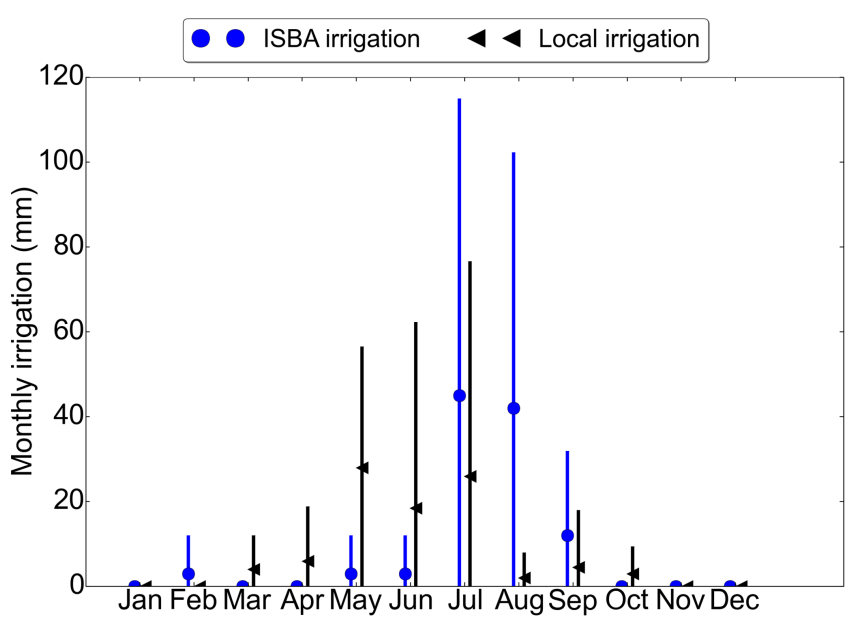

Figure 9. Comparison of the local and simulated mean monthly cumulative irrigation amount. The vertical bars represent the interannual variability ( \pm 1 standard deviation). The total cumulative value of in situ and simulated irrigation over 12 years are 1295 and $2070 \mathrm{~mm}$, respectively.

\subsubsection{Influence of vegetation dynamics}

The use of the ECOCLIMAP-II LAI in $\mathrm{S}_{\mathrm{ECO}-\mathrm{LAI}}$ triggers an overall overestimation of ET over 12 years (441 mm, 6\%). This is related to the overestimation of the mean LAI over the crop succession by ECOCLIMAP-II. The large scattering observed between $\mathrm{S}_{\mathrm{ECO}-\mathrm{LAI}}$ and $\mathrm{S}_{\mathrm{CTL}}$ (Fig. 12) is mainly related to the temporal mismatch between the ECOCLIMAP-II LAI cycle and the actual LAI cycle which leads to successive overestimation or underestimation of LAI over the crop succession. For winter crops, ET is frequently underestimated during the growing periods and overestimated at the end of 


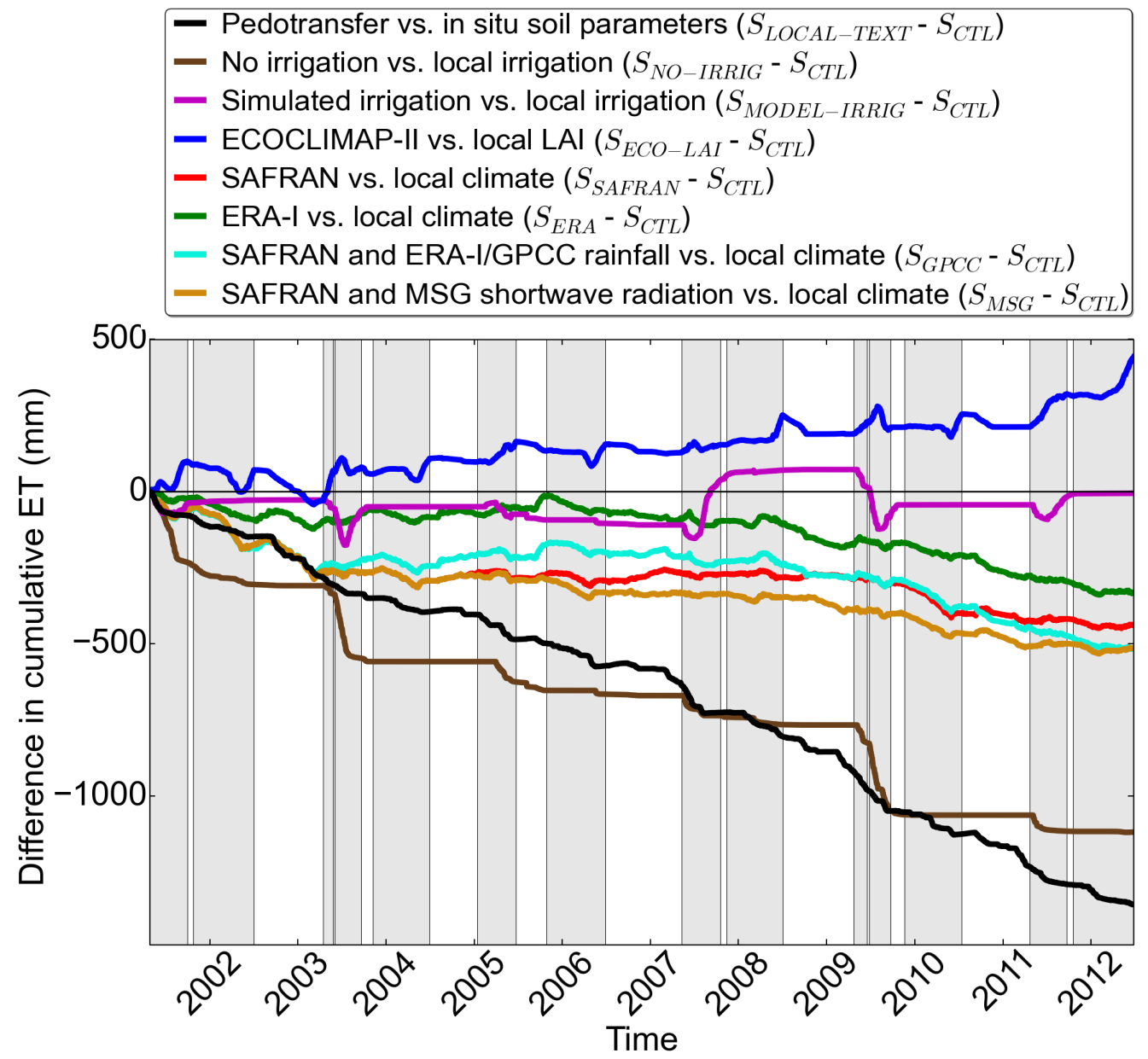

Figure 10. Differences in cumulative ET between each experiment achieved with the large-scale data set and the control run $\left(\mathrm{S}_{\mathrm{CTL}}\right)$ achieved with the local observations for each tested driver. Crop periods and inter-crop periods are represented by grey and white backgrounds, respectively.

the crop cycle during the senescence. For summer crops, ET is mainly overestimated. The decrease in ET observed during some inter-crop periods (mainly 2003) is due to the occurrence of crop regrowths which are not represented by the ECOCLIMAP-II LAI.

\subsubsection{Influence of climate variables}

The use of SAFRAN triggers an underestimation of ET (Fig. 10, Table 6). This is mainly related to the underestimation of longwave and shortwave radiations which decreases the surface energy available for ET. Slightly better performances scores are obtained for ERA-I which shows lower $\mathrm{MD}$ and lower scattering in ET with $\mathrm{S}_{\mathrm{CTL}}$ than SAFRAN at daily and longer timescales. This is related to the lower bias in ERA-I shortwave radiation. The higher SDD obtained with ERA-I at a half-hourly timescale is related to the higher dispersion found for the ERA-I radiations (Table 5). The use of the rainfall GPCC or the MSG shortwave radiation instead of the SAFRAN estimates have low influence on ET. A slight increase in SDD is obtained with the use of the GPCC rainfall which is related to its lower precision as mentioned above.

The differences in yearly ET between the reanalyses and the local climate simulations fall within similar range of values (from -137 to $3 \mathrm{~mm} \mathrm{yr}^{-1}$ for SAFRAN and from -83 to $40 \mathrm{~mm} \mathrm{yr}^{-1}$ for ERA-I/GPCC). Figure 5 shows that the evolution of the error in yearly ET is mainly related to the errors in rainfall. This particularly holds true for GPCC. The impacts of radiations are smaller except in 2008 and 2010 for SAFRAN.

\section{Discussion}

We discuss the implications of previous results with respect to the spatial integration of the model to monitor the water balance of cropland at regional scale. 

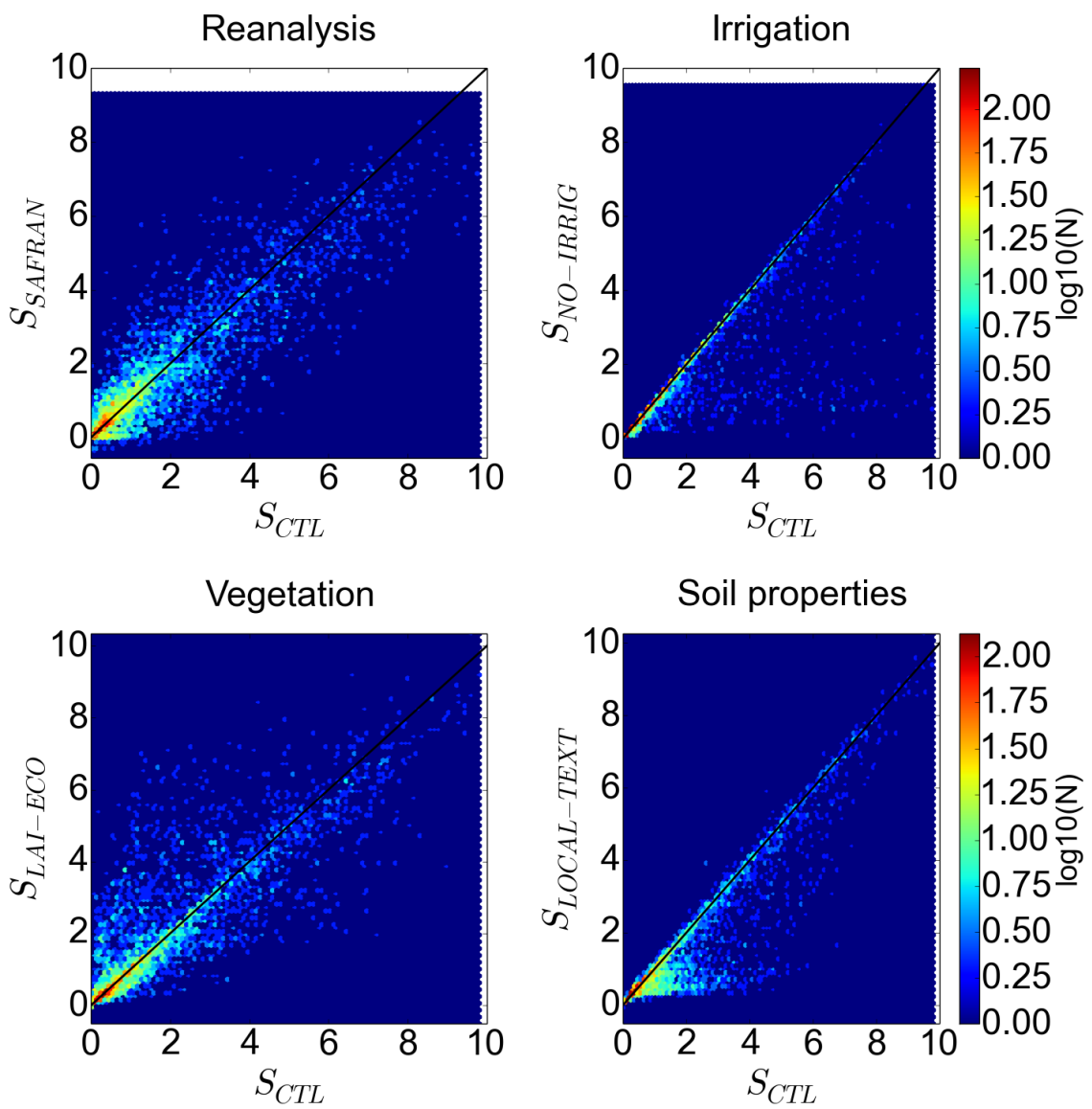

Figure 11. Scattering in daily ET between selected experiments and the control run. $N$ in the colour bar legend is the number of points used to represent the point density.

\subsection{Soil properties}

This study highlights the prevailing role of the soil hydrodynamic properties in retrieving the dynamics of ET. This particularly holds true for Mediterranean regions where ET is frequently limited by soil moisture. This supports findings from Smiatek et al. (2015) and Guillod et al. (2013), who report that differences in soil data sets can substantially affect regional climate simulation (up to $20 \%$ for precipitation). Besides, Guillod et al. (2013) and Garrigues et al. (2015) show the prevailing role of the soil parameters affecting the maximum available soil water capacity (field capacity and wilting point) which drives the transpiration and the parameters affecting the hydraulic diffusivity which influences the soil evaporation.

Since the soil hydraulic properties are rarely known over large areas, they are generally derived from empirical pedotransfer functions which relate the soil hydrodynamic properties to readily available variables such as soil texture and bulk density (Cosby et al., 1984; Vereecken et al., 1989; Schaap et al., 2001). Large discrepancies have been reported between pedotransfer functions which are prone to distinct sources of uncertainties (Espino et al., 1996; Baroni et al., 2010). The first shortcoming concerns their representativeness of soil property variability. The ISBA pedotransfer functions were established based on the Clapp and Hornberger (1978) database. These functions were calibrated using the mean values of the soil properties over few classes of soil texture. The variability of the soil parameters within a given soil texture class may exceed the variability between classes. Besides, global maps of soil texture may not be fine enough to describe the soil property variability at regional scale. The second source of uncertainty is related to the estimation method. While most pedotransfer functions are based on soil texture, improvements of the prediction equations may require the use of additional predictors related to soil structure (Vereecken et al., 1989). Most pedotransfer functions are based on simple statistical regressions such as the ISBA ones (Noilhan and Laccarère, 1995). The more advanced ROSETTA pedotransfer functions (Schaap et al., 2001) address the uncertainty in the predicted soil parameters through the use of an ensemble of functions calibrated over distinct soil data sets. Such model provides essential information on the variance and covariance of the hydraulic properties 


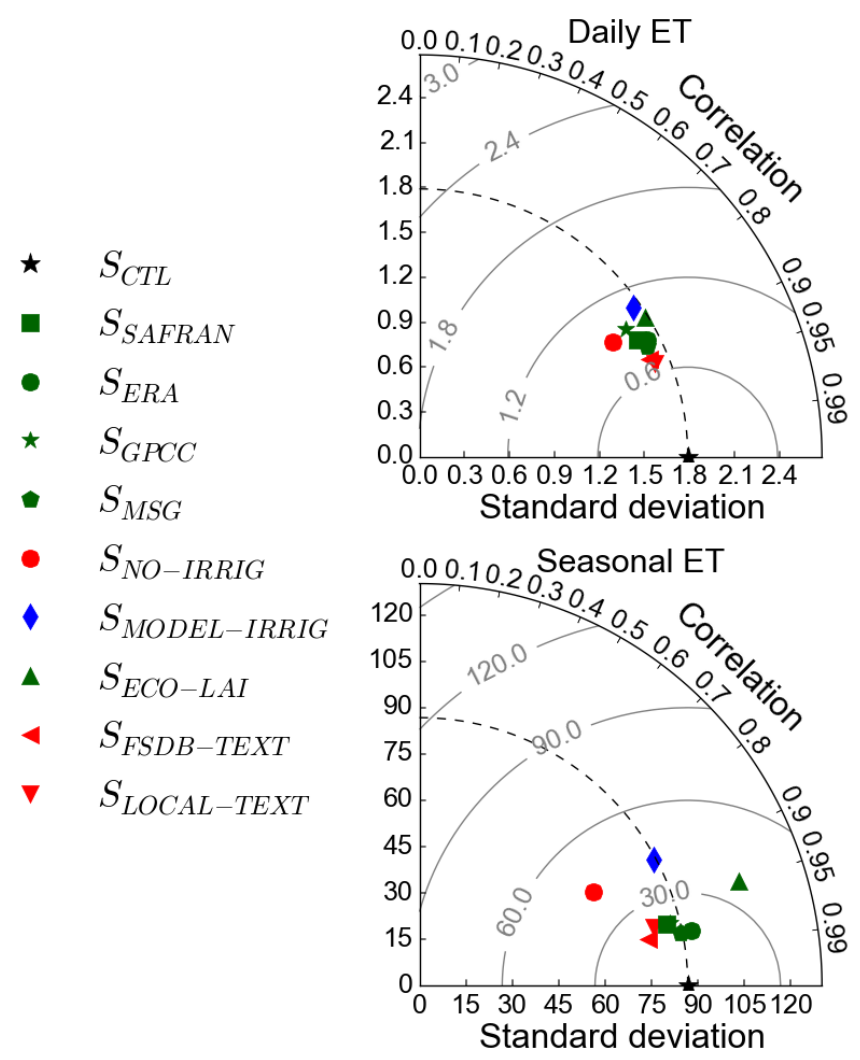

Figure 12. Deviations in daily and seasonal cumulative ET between each experiment and the control run $\left(\mathrm{S}_{\mathrm{CTL}}\right)$ summarized by a Taylor diagram (Taylor, 2001). The contour lines indicate the RMSD between each simulation and $\mathrm{S}_{\mathrm{CTL}}$. The $y$ axis indicates the standard deviation of each tested simulation while the $x$ axis indicates the standard deviation of $\mathrm{S}_{\mathrm{CTL}}$. The colours indicate the magnitude of the MD between each simulation and $\mathrm{S}_{\mathrm{CTL}}$. Blue indicates very low MD close to zero. Green indicates intermediate MD and red represents the largest MD. Numerical values are reported in Table 6.

(Scharnagl et al., 2011) which are required to propagate the uncertainties in the LSM simulations.

\subsection{Irrigation}

Irrigation is a key component of the water balance of Mediterranean cropland. It significantly modifies the seasonal pattern of evapotranspiration and can affect the regional climate (Puma and Cook, 2010; Leng et al., 2013). Besides, it is a key aspect of adaptation strategies to climate change. However, accurate information on irrigation amount is rarely available over large areas. The strategy consists in simulating the irrigation amount required to satisfy the crop water needs by the land surface model but, as demonstrated in this work, constraints on the irrigation period and the irrigation amount need to be incorporated to represent the actual agricultural practices more realistically. Adding the amount of irrigation water to rainfall may not be adapted for all types of irrigations (pressurized vs. gravity distribution). A more accurate description of the variability of irrigation practices needs to be incorporated in land surface models (Ozdogan et al., 2010; Olioso et al., 2013).

\subsection{Vegetation dynamic}

This work showed that the LAI climatology is not accurate enough to resolve ET dynamics over the crop succession. The key aspects that are lacking in the ECOCLIMAPII database and need to be better represented in land surface models are

- crop phenology, particularly the timing of maximum LAI;

- the succession of winter and summer crops which can lead to long periods of bare soil during inter-crop periods.

A strategy to resolve the temporal and spatial dynamics of vegetation would consist in using satellite observations. Recently launched satellites (e.g. next SENTINEL-2 satellite) have fine enough spatial resolution $(\sim 10 \mathrm{~m})$ and temporal frequency (5-10 days) to resolve the LAI cycle of crops more accurately and monitor the dynamics induced by crop rotation.

\subsection{Climate}

We showed that rainfall is the main climate driver of the errors in yearly ET. To monitor the water balance at regional scale, it is of paramount importance to improve the representation of the rainfall's spatiotemporal heterogeneity. While the SAFRAN rainfall is probably the most accurate and precise reanalysis data set over France, Zhao et al. (2012) showed that its spatial resolution may not be fine enough to resolve rainfall spatial heterogeneity. This particularly holds true for Mediterranean regions where rainfalls are governed more by local convective elements and mesoscale convection than by large-scale well-resolved dynamical processes (Anquetin et al., 2010; Szczypta et al., 2011; Bosilovich, 2013). The impact of the lack of irrigation on ET reported in this work provides an indication of the errors that could be generated by the use of inaccurate rainfall forcing over large areas. High resolution rainfall data sets derived from the combination of terrestrial rainfall radar data, in situ observations and atmospheric models need to be developed to better resolve rainfall spatial heterogeneity at regional scale.

\section{Summary}

The present study aims at evaluating the large-scale data sets used to drive the ISBA-A-gs land surface model and assessing their impacts on the simulation of ET over a 12year Mediterranean crop succession. We focus on the climate (rainfall, radiations), irrigation, vegetation dynamic (LAI) 
and soil property (soil texture, hydrodynamic parameters) variables. We evaluate the forcing data sets used in the standard implementation of the ISBA model over France where the model is driven by the SAFRAN high spatial resolution atmospheric reanalysis, the LAI time courses derived from the ECOCLIMAP-II land surface parameter database and the soil texture derived from the French soil database. For climate, additional data sets used to drive the model at the continental scale are tested, which includes the ERA-Interim low spatial resolution reanalysis, the GPCC rainfall data set and the downwelling shortwave radiation derived from the MSG satellite. We first evaluate the large-scale data set against the local values taken at the Avignon site. Then, we assess the hierarchy of the influence of each driver on ET. We finally discuss the implications of our results with respect to the spatial integration of the model to monitor the water balance of cropland at regional scale.

The main outcomes from the evaluation of the drivers are as follows.

- SAFRAN and ERA-I/GPCC rainfall are quasi-unbiased at daily and longer timescales ( 1 and $0.5 \%$ of the mean rainfall measurement). The SAFRAN rainfall is more precise than the ERA-I/GPCC rainfall which shows larger inter-annual variability in yearly rainfall error (up to $100 \mathrm{~mm}$ ).

- ERA-I has a very low bias $\left(2.5 \mathrm{~W} \mathrm{~m}^{-2}\right)$ in daily downwelling shortwave radiation while SAFRAN and MSG show negative biases of $\sim-10 \mathrm{~W} \mathrm{~m}^{-2}$. Both SAFRAN and ERA-I underestimate downwelling longwave radiations by -12 and $-16 \mathrm{~W} \mathrm{~m}^{-2}$, respectively.

- The ECOCLIMAP-II LAI climatology does not properly resolve Mediterranean crop phenology. It does not describe the succession of winter and summer crops and underestimates the bare soil period which leads to an overall overestimation of LAI over the crop succession.

- Irrigation generates much larger variations in incoming water for the model than the differences in rainfall between the reanalysis data sets. The simulation of irrigation by the model provides accurate irrigation amounts over the crop cycle but the timing of irrigation occurrences is frequently unrealistic.

The main results from the evaluation of the impacts on ET are the following.

- Errors in the soil hydrodynamic parameters and the lack of irrigation in the simulation have the largest influence on ET compared to uncertainties in the large-scale climate reanalysis and the LAI climatology. Among climate variables, the errors in yearly ET are mainly related to the errors in yearly rainfall.
- The underestimation of the maximum soil water capacity and the soil hydraulic diffusivity induce a large underestimation of ET over 12 years.

- The errors in the climate data sets and the absence of irrigation in the simulation lead to the underestimation of ET while the overall overestimation of LAI by the ECOCLIMAP-II climatology induces an overestimation of ET over 12 years.

This work shows that the key challenges for the spatial integration of a land surface model over Mediterranean cropland concern the representation of the following.

- The spatial distribution of the soil hydrodynamic parameters which control the available water capacity and the soil hydraulic diffusivity.

- The variability of irrigation practices in land surface models. Irrigation was proved to have large influence on long time-series of ET although it concerns only short periods of time during the crop succession.

- The spatiotemporal variability of rainfall, which can be particularly important for Mediterranean climate characterized by local convective elements.

- The vegetation dynamic at seasonal (phenology) and inter-annual (crop rotation) timescales.

A strategy combining models and new remote sensing observations with high spatial resolution $(\sim 10-20 \mathrm{~m})$ and high temporal frequency (5-10 days) offers great promise for resolving the vegetation dynamic and retrieving the spatial distribution of soil properties for cropland and therefore needs to be fostered in future.

Edited by: G. A. Folberth

\section{References}

Anquetin, S., Braud, I., Vannier, O., Viallet, P., Boudevillain, B., Creutin, J.-D., and Manus, C.: Sensitivity of the hydrological response to the variability of rainfall fields and soils for the Gard 2002 flash-flood event, J. Hydrol., 394, 134-147, 2010.

Avissar, R. and Pielke, R. A.: A parameterization of heterogeneous land surfaces for atmospheric numerical models and its impact on regional meteorology, Mon. Weather Rev., 117, 2113-2136, 1989.

Barbu, A. L., Calvet, J.-C., Mahfouf, J.-F., and Lafont, S.: Integrating ASCAT surface soil moisture and GEOV1 leaf area index into the SURFEX modelling platform: a land data assimilation application over France, Hydrol. Earth Syst. Sci., 18, 173-192, doi:10.5194/hess-18-173-2014, 2014.

Baroni, G., Facchi, A., Gandolfi, C., Ortuani, B., Horeschi, D., and van Dam, J. C.: Uncertainty in the determination of soil hydraulic parameters and its influence on the performance of two hydrological models of different complexity, Hydrol. Earth Syst. Sci., 14, 251-270, doi:10.5194/hess-14-251-2010, 2010. 
Bosilovich, M.: Regional climate and variability of nasa merra and recent reanalyses: u.s. summertime precipitation and temperature, J. Appl. Meteor. Climatol., 52, 1939-1951, 2013.

Bosilovich, M., Kennedy, J., Dee, D., Allan, R., and O'Neill, A.: On the reprocessing and reanalysis of observations for climate, Climate Science for Serving Society: Research, Modeling and Prediction Priorities, edited by: Asrar, G. R. and Hurrell, J. W., Springer, 51-71, 2013.

Braud, I., Dantas-Antonio, A. C., and Vauclin, M.: A stochastic approach to studying the influence of the spatial variability of soil hydraulic properties on surface fluxes, temperature and humidity, J. Hydrol., 165, 283-310, 1995.

Calvet, J.-C., Noilhan, J., Roujean, J.-L., Bessemoulin, P., Cabelguenne, M., Olioso, A., and Wigneron, J.-P.: An interactive vegetation SVAT model tested against data from six contrasting sites, Agr.Forest Meteorol., 92, 73-95, 1998.

Calvet, J.-C., Gibelin, A.-L., Roujean, J.-L., Martin, E., Le Moigne, P., Douville, H., and Noilhan, J.: Past and future scenarios of the effect of carbon dioxide on plant growth and transpiration for three vegetation types of southwestern France, Atmos. Chem. Phys., 8, 397-406, doi:10.5194/acp-8-397-2008, 2008.

Calvet, J.-C., Lafont, S., Cloppet, E., Souverain, F., Badeau, V., and Le Bas, C.: Use of agricultural statistics to verify the interannual variability in land surface models: a case study over France with ISBA-A-gs, Geosci. Model Dev., 5, 37-54, doi:10.5194/gmd-537-2012, 2012.

Carrer, D., Lafont, S., Roujean, J. L., Calvet, J. C., Meurey, C., Le Moigne, P., and Trigo, I.: Incoming solar and infrared radiation derived from METEOSAT: impact on the modelled land water and energy budget over France, J. Hydrometeorol., 13, 504-520, 2012.

Clapp, R. and Hornberger, G.: Empirical equations for some soil hydraulic properties, Water Resour. Res., 14, 601-604, 1978.

Cosby, B. J., Hornberger, G. M., Clapp, R. B., and Ginn, T. R.: A statistical exploration of the relationships of soil moisture characteristics to the physical properties of soils, Water Resour. Res., 20, 682-690, 1984.

Decharme B. and Douville, H.: Uncertainties in the GSWP2 precipitation forcing and their impacts on regional and global hydrological simulations, Clim. Dynam., 27, 695-713, doi:10.1007/s00382-006-0160-6, 2006.

Decker, M., Brunke, M. A., Wang, Z., Sakaguchi, K., Zeng, X., and Bosilovich, M. G.: Evaluation of the reanalysis products from GSFC, NCEP, and ECMWF using flux tower observations, J. Climate, 25, 1916-1944, 2012.

Déqué, M., Dreveton C., Braun, A., and Cariolle D.: The ARPEGE/IFS atmosphere model: a contribution to the French community climate modelling, Clim. Dynam., 10, 249-266, doi:10.1007/BF00208992, 1994.

de Rosnay, P., Polcher, J., Laval, K., and Sabre, M.: Integrated parameterization of irrigation in the land surface model ORCHIDEE, Validation over Indian Peninsula, Geophys. Res. Lett., 30, 1986, doi:10.1029/2003GL018024, 2003.

Duveiller, G., Weiss, M., Baret, F., and Defourny, P.: Retrieving wheat Green Area Index during the growing season from optical time series measurements based on neural network radiative transfer inversion, Remote Sens. Environ., 115, 887-896, 2011.
Espino, A., Mallants, D., Vanclooster, M., Feyen, J.: Cautionarynotes on the use of pedotransfer functions for estimating soil hydraulic properties, Agric. Water Manage., 29, 235-253, 1996.

Faroux, S., Kaptué Tchuenté, A. T., Roujean, J.-L., Masson, V., Martin, E., and Le Moigne, P.: ECOCLIMAP-II/Europe: a twofold database of ecosystems and surface parameters at $1 \mathrm{~km}$ resolution based on satellite information for use in land surface, meteorological and climate models, Geosci. Model Dev., 6, 563582, doi:10.5194/gmd-6-563-2013, 2013.

Garrigues, S., Lacaze, R., Baret, F., Morisette, J. T., Weiss, M., Nickeson, J., Fernandes, R., Plummer, S., Shabanov, N. V., Myneni, R., Knyazikhin, Y., and Yang, W.: Validation and inter-comparison of global Leaf Area Index product derived from remote sensing data, J. Geophys. Res., 113, G02028, doi:10.1029/2007JG000635, 2008.

Garrigues, S., Olioso, A., Calvet, J. C., Martin, E., Lafont, S., Moulin, S., Chanzy, A., Marloie, O., Buis, S., Desfonds, V., Bertrand, N., and Renard, D.: Evaluation of land surface model simulations of evapotranspiration over a 12-year crop succession: impact of soil hydraulic and vegetation properties, Hydrol. Earth Syst. Sci., 19, 3109-3131, doi:10.5194/hess-19-31092015, 2015.

Ge, J., Qi, J., Lofgren, B. M., Moore, N., Torbick, N., and Olson, J. M.: Impacts of land use/ classification accuracy on regional climate simulations, J. Geophy. Res., 112, D05107, doi:10.1029/2006JD007404, 2007.

Geiger, B., Meurey, C., Lajas, D., Franchisteguy, L., Carrer, D., and Roujean, J.-L.: Near real-time provision of downwelling shortwave radiation estimates derived from satellite observations, Meteor. Appl., 15, 411-420, 2008.

Gibelin, A.-L., Calvet, J.-C., Roujean, J.-L., Jarlan, L., and Los, S. O.: Ability of the land surface model ISBA-A-gs to simulate leaf area index at the global scale: Comparison with satellites products, J. Geophys. Res., 111, 1-16, 2006.

Goudriaan, J., van Laar, H. H., van Keulen, H., and Louwerse, W.: Photosynthesis, CO 2 and plant production, in: Wheat Growth and Modelling, edited by: Day, W. and Atkin, R. K., NATO ASI Series, Plenum Press, New York, Series A, 86, 107-122, 1985.

Guillod, B. P., Davin, E. L., Kündig, C., Smiatek, G., and Seneviratne, S. I.: Impact of soil map specifications for European climate simulations, Clim. Dynam., 40, 123-141, doi:10.1007/s00382-012-1395-z, 2013.

Habets, F., Boone, A., Champeaux, J. L., Etchevers, P., Franchisteguy, L., Leblois, E., Ledoux, E., Moigne, P. L., Martin, E., Morel, S., Noilhan, J., and Viennot, P.: The SAFRAN-ISBAMODCOU hydrometeorological model applied over France, J. Geophys. Res., 113, 1-18, 2008.

Jacobs, C. M. J., Van den Hurk, B. J. J. M., and De Bruin, H. A. R.: Stomatal behaviour and photosynthetic rate of unstressed grapevines in semi-arid conditions, Agr. Forest Meteorol., 80, 111-134, 1996.

King, D., Lebas, C., Jamagne, M., Hardy, R., and Daroussin, J.: Base de données géographiques des sols de France a l'échelle 1/1000000 (Geographical Soil Database for France at a scale of 1/1000000), Technical report, 100 pp., Institut National de Recherches Agronomiques (INRA), orleans, France, available at: http://www.gissol.fr/programme/bdgsf/bdgsf.php, 1995.

Lafont, S., Zhao, Y., Calvet, J.-C., Peylin, P., Ciais, P., Maignan, F., and Weiss, M.: Modelling LAI, surface water and carbon 
fluxes at high-resolution over France: comparison of ISBA-A-gs and ORCHIDEE, Biogeosciences, 9, 439-456, doi:10.5194/bg9-439-2012, 2012.

Leng, G., Huang, M., Tang, Q., Sacks, W. J., Lei, H., and Leung, L. R.: Modeling the effects of irrigation on land surface fluxes and states over the conterminous United States: Sensitivity to input data and model parameters, J. Geophys. Res. Atmos., 118, 97899803, doi:10.1002/jgrd.50792, 2013.

Maggioni, V., Anagnostou, E. N., and Reichle, R. H.: The impact of model and rainfall forcing errors on characterizing soil moisture uncertainty in land surface modeling, Hydrol. Earth Syst. Sci., 16, 3499-3515, doi:10.5194/hess-16-3499-2012, 2012.

Masson, V., Champeaux, J.-L., Chauvin, F., Meriguet, C., and Lacaze, R.: A global database of land surface parameters at 1-km resolution in meteorological and climate models, J. Climate, 16, 1261-1282, 2003.

Masson, V., Le Moigne, P., Martin, E., Faroux, S., Alias, A., Alkama, R., Belamari, S., Barbu, A., Boone, A., Bouyssel, F., Brousseau, P., Brun, E., Calvet, J.-C., Carrer, D., Decharme, B., Delire, C., Donier, S., Essaouini, K., Gibelin, A.-L., Giordani, H., Habets, F., Jidane, M., Kerdraon, G., Kourzeneva, E., Lafaysse, M., Lafont, S., Lebeaupin Brossier, C., Lemonsu, A., Mahfouf, J.-F., Marguinaud, P., Mokhtari, M., Morin, S., Pigeon, G., Salgado, R., Seity, Y., Taillefer, F., Tanguy, G., Tulet, P., Vincendon, B., Vionnet, V., and Voldoire, A.: The SURFEXv7.2 land and ocean surface platform for coupled or offline simulation of earth surface variables and fluxes, Geosci. Model Dev., 6, 929-960, doi:10.5194/gmd-6-929-2013, 2013.

Miralles, D. G., De Jeu, R. A. M., Gash, J. H., Holmes, T. R. H., and Dolman, A. J.: Magnitude and variability of land evaporation and its components at the global scale, Hydrol. Earth Syst. Sci., 15, 967-981, doi:10.5194/hess-15-967-2011, 2011.

Noilhan, J. and Lacarrère, P.: GCM Grid-Scale Evaporation from Mesocale Modeling, J. Climate, 8, 206-223, 1994.

Noilhan, J. and Planton, S.: A simple parameterization of land surface processes for meteorological models, Mon. Weather Rev., 117, 536-549, 1989.

Noilhan, J. and Mahfouf, J.-F.: The ISBA land surface parameterisation scheme, Global Planet. Change, 13, 145-159, 1996.

Noilhan, J., Donier, S., Sarrat, C., and Moigne, P. L.: Regional-scale evaluation of a land surface scheme from atmospheric boundary layer observations, J. Geophys. Res., 116, 1-17, 2011.

Olioso, A., Inoue, Y., Ortega-FARIAS, S., Demarty, J., Wigneron, J.-P., Braud, I., Jacob, F., Lecharpentier, P., OttlÉ, C., Calvet, J.C., and Brisson, N.: Future directions for advanced evapotranspiration modeling: Assimilation of remote sensing data into crop simulation models and SVAT models, Irrigat. Drain. Syst., 19, 377-412, 2005.

Olioso A., Lecerf R., Baillieux A., Chanzy A., Ruget F., Banton O., Lecharpentier P., Trolard F., and Cognard-Plancq A.-L.: Modelling of drainage and hay production over the Crau aquifer for analysing impact of global change on aquifer recharge, Procedia Environmental Sciences, 19, 69-700, 2013.

Ozdogan, M., Rodell, M., Beaudoing, H. K., and Toll, D. L.: Simulating the Effects of Irrigation over the United States in a Land Surface Model Based on Satellite-Derived Agricultural Data, J. Hydrometeorol., 11, 171-184, doi:10.1175/2009JHM1116.1, 2010.
Pijanowski, B., Moore, N., Mauree, D., and Niyogi, D.: Evaluating error propagation in coupled land-atmosphere models, Earth Interact., 15, 110812084039007, doi:10.1175/2011EI380.1, 2011.

Puma, M. J. and Cook, B. I.: Effects of irrigation on global climate during the 20th century, J. Geophys. Res., 115, D16120, doi:10.1029/2010JD014122, 2010.

Quintana-Seguí, P., Le Moigne, P., Durand, Y., Martin, E., Habets, F., Baillon, M., Canellas, C., Franchisteguy, L., and Morel, S.: Analysis of Near-Surface Atmospheric Variables: Validation of the SAFRAN Analysis over France, J. Appl. Meteorol. Climatol., 47, 92-107, 2008.

Ritter, B. and Geleyn, J.-F.: A comprehensive radiation scheme for numerical weather prediction models with potential applications in climate simulations, Mon. Weather Rev., 120, 303-325, 1992.

Schaap, M. G., Leij, F. J., and van Genuchten, M. T.: ROSETTA: a computer program for estimating soil hydraulic parameters with hierarchical pedotransfer functions, J. Hydrol., 251, 163-176, 2001.

Scharnagl, B., Vrugt, J. A., Vereecken, H., and Herbst, M.: Inverse modelling of in situ soil water dynamics: investigating the effect of different prior distributions of the soil hydraulic parameters, Hydrol. Earth Syst. Sci., 15, 3043-3059, doi:10.5194/hess-153043-2011, 2011.

Schneider, U., Becker, A., Finger, P., Meyer-Christoffer, A., Rudolf, B., and Ziese, M.: GPCC Full Data Reanalysis Version 6.0 at $0.5^{\circ}$ : Monthly Land-Surface Precipitation from Rain-Gauges built on GTS-based and Historic Data, 2011.

Simmons, A. J., Willett, K. M., Jones, P. D., Thorne, P. W., and Dee, D. P.: Low-frequency variations in surface atmospheric humidity, temperature and precipitation: Inferences from reanalyses and monthly gridded observational data sets, J. Geophys. Res., 115, D01110, doi:10.1029/2009JD012442, 2010.

Smiatek, G., Helmert, J., and Gerstner, E.-M: Impact of land use and soil data specifications on COSMO-CLM simulations in the CORDEX-MED area, Meteorol. Z., doi:10.1127/metz/2015/0594, 2015.

Szczypta, C., Calvet, J.-C., Albergel, C., Balsamo, G., Boussetta, S., Carrer, D., Lafont, S., and Meurey, C.: Verification of the new ECMWF ERA-Interim reanalysis over France, Hydrol. Earth Syst. Sci., 15, 647-666, doi:10.5194/hess-15-647-2011, 2011.

Taylor, K. E.: Summarizing multiple aspects of model performance in a single diagram, J. Geophys. Res., 106, 7183-7192, 2001.

Teuling, A. J., Hirschi, M., Ohmura, A., Wild, M., Reichstein, M., Ciais, P., Buchmann, N., Ammann, C., Montagnani, L., Richardson, A. D., Wohlfahrt, G., and Seneviratne, S. I.: A regional perspective on trends in continental evaporation, Geophys. Res. Lett., 36, L02404, doi:10.1029/2008GL036584, 2009.

Vereecken, H., Maes, J., and Darius, P.: Estimating the soil moisture retention characteristic from texture, bulk density and carbon content, Soil Sci., 148, 389-403, 1989.

Vidal, J.-P., Martin, E., Franchistéguy, L., Habets, F., Soubeyroux, J.-M., Blanchard, M., and Baillon, M.: Multilevel and multiscale drought reanalysis over France with the Safran-Isba-Modcou hydrometeorological suite, Hydrol. Earth Syst. Sci., 14, 459-478, doi:10.5194/hess-14-459-2010, 2010a.

Vidal, J.-P., Martin, E., Franchistéguy, L., Baillon, M., and Soubeyroux, J.-M.: A 50-year high-resolution atmospheric reanalysis over France with the Safran system, Int. J. Climatol., 30, 16271644, 2010b. 
Wang, A. and Zeng, X.: Evaluation of multireanalysis products with in situ observations over the Tibetan Plateau, J. Geophys. Res., 117, D05102, doi:10.1029/2011JD016553, 2012.

Zhao, T., Guo, W., and Fu, C.: Calibrating and Evaluating Reanalysis Surface Temperature Error by Topographic Correction, J. Climate, 21, 1440-1446, 2008.
Zhao, Y., Ciais, P., Peylin, P., Viovy, N., Longdoz, B., Bonnefond, J. M., Rambal, S., Klumpp, K., Olioso, A., Cellier, P., Maignan, F., Eglin, T., and Calvet, J. C.: How errors on meteorological variables impact simulated ecosystem fluxes: a case study for six French sites, Biogeosciences, 9, 2537-2564, doi:10.5194/bg-92537-2012, 2012. 